\title{
Selection and Characterisation of Oenococcus oeni and Lactobacillus plantarum South African Wine Isolates for Use as Malolactic Fermentation Starter Cultures
}

\author{
E. Lerm, L. Engelbrecht \& M. du Toit \\ Institute for Wine Biotechnology, Department of Viticulture and Oenology, Stellenbosch University, Private Bag X1, \\ Matieland (Stellenbosch), South Africa
}

Submitted for publication: May 2011

Accepted for publication: September 2011

Key words: Malolactic fermentation, Oenococcus oeni, Lactobacillus plantarum, starter cultures, enzyme encoding genes

\begin{abstract}
This study focused on characterising 23 Oenococcus oeni and 19 Lactobacillus plantarum strains isolated from the South African wine environment for the development of potential commercial malolactic fermentation (MLF) starter cultures. These strains were characterised with regards to oenological important characteristics, including the genetic screening for enzyme-encoding genes (enzymes that are involved/implicated in wine aroma modification, as well as enzymes pertaining to the wholesomeness of the final wine product), their fermentation capabilities, the ability to maintain viability during MLF, as well as the volatile acidity production. A total of three $O$. oeni and three $L$. plantarum strains were selected at the completion of this study. These six strains showed the most potential during the characterisation stages of the study and were able to successfully complete MLF in Pinotage wine. It was also found that $L$. plantarum strains displayed a more diverse enzyme profile than $O$. oeni strains, particularly with regards to the presence of the aroma-modifying enzymes $\beta$-glucosidase and phenolic acid decarboxylase (PAD), which implies the future use of this species in the modification of the wine aroma profile and use as commercial starter culture.
\end{abstract}

\section{INTRODUCTION}

Malolactic fermentation (MLF) in wine is a deacidification process consisting of the decarboxylation of L-malic acid by the malolactic enzyme and is a result of the metabolic activity of lactic acid bacteria (LAB). During this fermentation process L-malic acid is decarboxylated to produce L-lactic acid and carbon dioxide. The three main reasons for allowing MLF to take place is the resulting deacidification, microbiological stability and the associated modifications in the aroma profile of the wine (Wibowo et al., 1985; Lerm et al., 2010). The indigenous LAB population associated with the wine environment usually belongs to the genera of Oenococcus, Lactobacillus, Pediococcus and Leuconostoc (Lonvaud-Funel, 1999). Oenococcus oeni is the species of LAB that is most often responsible for MLF and has shown to be able to successfully survive the challenging wine environment. Some of these challenges include high alcohol concentrations, low $\mathrm{pH}$, extreme fermentation temperatures and the presence of sulphur dioxide $\left(\mathrm{SO}_{2}\right)$ (Davis et al., 1988; Drici-Cachon et al., 1996). Currently, $O$. oeni is the major LAB used in commercial starter cultures for MLF. Some Lactobacillus species have also displayed the ability to survive the harsh wine conditions (G-Alegría et al., 2004; Pozo-Bayón et al., 2005), of which the species
Lactobacillus plantarum has shown the most potential as a starter culture (for review see Du Toit et al., 2010) and a commercial culture has recently been released by Lallemand as Lactobacillus plantarum V22 ${ }^{\circledR}$ (Bou \& Krieger, 2004; Fumi et al., 2010). This species of Lactobacillus also shows a more diverse enzymatic profile than $O$. oeni (Matthews et al., 2004; Spano et al., 2005; Mtshali et al., 2010), which could play an important role in the modification of the wine aroma profile (Guerzoni et al., 1995; Swiegers et al., 2005; Matthews et al., 2006).

There are various important criteria to consider when selecting LAB for possible use in a starter culture. These include the ability to tolerate low $\mathrm{pH}$, high ethanol and $\mathrm{SO}_{2}$ concentrations, good growth characteristics under winemaking conditions, compatibility with the selected yeast strain, the inability to produce biogenic amines and the lack of off-flavour or off-odour production (Wibowo et al., 1985; Britz \& Tracey, 1990; Henick-Kling, 1993; LonvaudFunel, 2001; Ruiz et al., 2010; Solieri et al., 2010).

There are various enzymes originating from LAB that could potentially contribute to the sensory profile and wholesomeness of wines undergoing MLF. Some of the aroma-related enzymes include $\beta$-glucosidase, phenolic

*Corresponding author: E-mail: mdt@sun.ac.za

Aknowledgements: This study was financially supported by Anchor Yeast and THRIP. 
acid decarboxylase (PAD), citrate lyase, esterase, protease, peptidases, $\alpha$-acetolactate synthase and $\alpha$-acetolactate reductase (Spano et al., 2005; Sumby et al., 2009; Brod et al., 2010; Mtshali et al., 2010), as well as enzymes that play a role in the production of volatile sulphur compounds, including $S$-adenosylmethionine synthase, cystathionine $\beta / \gamma$-lyase and glutathione reductase (Knoll et al., 2010). Other enzymes of interest that play a negative role in the wholesomeness of the wine, besides those enzymes implicated in biogenic amine production, include those that are involved in ethyl carbamate formation, a potential carcinogen. These enzymes are carbamate kinase, ornithine transcarbamylase and arginine deiminase, related to arginine metabolism (Liu et al., 1995; Arena et al., 2002).

The overall aim of the study was to evaluate $O$. oen $i$ and $L$. plantarum strains isolated from South African wines for use as possible MLF starter cultures. The first objective was to characterise the isolates in order to identify potential starter strains. This was done by assessing the malic acid degradation rate of the isolates in a synthetic wine medium and screening the isolates for the presence of genes that play a role in the production of biogenic amines and ethyl carbamate, as well as other enzymes important in aroma production. The second objective was to select and evaluate the viability, MLF rate and volatile acidity production of the most promising strains in Pinotage wine inoculated after alcoholic fermentation (AF).

\section{MATERIALS AND METHODS}

Bacterial isolates, media and culture conditions

Oenococcus oeni and L. plantarum strains selected for use in this study were taken from the Institute for Wine Biotechnology (IWBT) (Stellenbosch University, South Africa) culture collection, as well as isolates from spontaneous MLF in Pinotage wine from the Paarl region, South Africa. Table 1 lists the bacterial strains used in this study. The identity of these strains was confirmed as $O$. oeni or L. plantarum (Lerm, 2010).

Representative sampling of the grape must were done for microbiological enumeration before MLF and on a weekly basis for the duration of the fermentation. The microbiological population was monitored by plate counts of colonies (CFU/mL) formed on selected media. Lactobacillus plantarum strains were cultivated on De Man, Rogosa and Sharpe (MRS) agar plates containing MRS broth (Biolab, Merck) and Bacteriological agar (Biolab, Merck). Oenococcus oeni strains were cultivated on MRST agar containing MRS and $20 \mathrm{~g} / \mathrm{L}$ Bacteriological agar supplemented with $10 \%$ preservative free tomato juice (All Gold, South Africa) with the $\mathrm{pH}$ adjusted to 5.0 with hydrochloric acid $(\mathrm{HCl})$. All plates contained $50 \mathrm{mg} / \mathrm{L}$ Delvocid Instant (DSM Food Specialties, The Netherlands) to prevent the growth of yeasts and $25 \mathrm{mg} / \mathrm{L}$ Kanamycin Sulphate (Roche Diagnostics GmbH, Mannheim, Germany) to suppress the growth of acetic acid bacteria. Grape must or

TABLE 1

A list of the strains that were selected from the IWBT culture collection and isolated from spontaneous MLF in Pinotage.

\begin{tabular}{|c|c|c|c|}
\hline Isolate & Species & Isolate & Species \\
\hline B69 & O. oеni & 2.1 & L. plantarum \\
\hline D59 & O. oеni & 14 & L. plantarum \\
\hline D60 & O. oeni & 14.1 & L. plantarum \\
\hline E53 & O. oеni & 56 & L. plantarum \\
\hline $\mathrm{J} 65$ & O. oеni & 65 & L. plantarum \\
\hline M69 & O. оепі & 66.1 & L. plantarum \\
\hline N73 & O. oеni & 68 & L. plantarum \\
\hline W56 & O. oеni & 69 & L. plantarum \\
\hline W75 & O. оепі & 70 & L. plantarum \\
\hline W77 & O. oеni & 71 & L. plantarum \\
\hline A1 & O. oеni & 71.1 & L. plantarum \\
\hline $\mathrm{A} 2$ & O. оепі & 73.1 & L. plantarum \\
\hline B1 & O. oеni & 75 & L. plantarum \\
\hline $\mathrm{C} 1$ & O. oеni & 76.2 & L. plantarum \\
\hline $\mathrm{S} 1 *$ & O. оепі & 77.1 & L. plantarum \\
\hline $\mathrm{S} 2 *$ & O. oеni & 78.1 & L. plantarum \\
\hline $\mathrm{S} 3 *$ & O. oеni & 80.2 & L. plantarum \\
\hline $\mathrm{S} 4 *$ & O. оепі & 107 & L. plantarum \\
\hline $\mathrm{S} 5 *$ & O. oеni & 109 & L. plantarum \\
\hline S6* & O. оепi & & \\
\hline $\mathrm{S} 7 *$ & O. оепі & & \\
\hline $\mathrm{S} 8 *$ & O. oеni & & \\
\hline S9* & O. oеni & & \\
\hline
\end{tabular}

* Strains isolated from spontaneous MLF in Pinotage. 
wine samples were serially diluted ten-fold in sterile water and plated. All LAB were anaerobically cultivated by using Microbiology Anaerocult sheets in anaerobic jars (Merck, Darmstadt, Germany) and incubated at $30^{\circ} \mathrm{C}$ for four to seven days depending on the growth of the microorganisms. Colonies were also inspected using light microscopy to investigate the cell morphology.

The culturing of the LAB strains prior to inoculation in the wine were as follow: L. plantarum and $O$. oeni strains were grown at $30^{\circ} \mathrm{C}$ on MRS agar and MRST agar plates, respectively, until single colonies were clearly distinguishable. After growth on the agar plates, L. plantarum strains were grown at $30^{\circ} \mathrm{C}$ in MRS broth for two days and $O$. oeni strains were grown in filter-sterilised MRS broth supplemented with $20 \%$ preservative free apple juice (Ceres, South Africa) (MRSA) and the $\mathrm{pH}$ adjusted to 5.2 with $\mathrm{HCl}$ for four days. To ensure survival in the wine after inoculation, strains grown in MRS and MRSA broth were inoculated in an adaptation medium at $1.5 \%(\mathrm{v} / \mathrm{v})$ and incubated at $30^{\circ} \mathrm{C}$ for two days. The adaptation medium consisted of (concentrations indicated in brackets): MRS (Biolab, Merck; $50 \mathrm{~g} / \mathrm{L}$ ), D(-)-fructose (Merck; $40 \mathrm{~g} / \mathrm{L}$ ), $\mathrm{D}(+)$-glucose (Merck; $20 \mathrm{~g} / \mathrm{L}), \mathrm{L}(-)$-malic acid (Sigma; $4 \mathrm{~g} / \mathrm{L})$, Tween 80 (Merck; $1 \mathrm{~g} / \mathrm{L})$, absolute ethanol (4\% v/v) and with the $\mathrm{pH}$ adjusted to 4.6 using potassium hydroxide $(\mathrm{KOH})$ pellets (Saarchem, Merck). The adaptation medium for $O$. oeni strains were filter-sterilised using a $0.22 \mu \mathrm{m}$ syringe filter and also supplemented with $20 \%$ preservative free apple juice. After two days in the adaptation medium, the cultures were centrifuged at $8000 \mathrm{rpm}$ for $10 \mathrm{~min}$ and the pellet rehydrated in water before inoculation in the wine at approximately $10^{6} \mathrm{CFU} / \mathrm{mL}$.

\section{Screening in synthetic wine medium}

For evaluation in the synthetic wine medium, L. plantarum strains were cultivated at $30^{\circ} \mathrm{C}$ in MRS broth for two days. Oenococcus oeni strains were cultivated at $30^{\circ} \mathrm{C}$ for four days in filter-sterilised MRSA broth. The ability of the bacterial strains to degrade malic acid was evaluated in a synthetic wine medium adapted from Ugliano et al. (2003). The media was prepared with the following adaptations: the $\mathrm{pH}$ of the medium was adjusted to 3.4 with $\mathrm{KOH}$ pellets and the ethanol concentration was adjusted to $14 \%(\mathrm{v} / \mathrm{v})$ using absolute ethanol (Saarchem, Merck). No glycoside extract was added and $0.056 \mathrm{~g} / \mathrm{L} \mathrm{MnSO}_{4} \cdot \mathrm{H}_{2} \mathrm{O}$ was added as a substitute for $\mathrm{MnSO}_{4}$. The media was filtered through a $0.45 \mu \mathrm{m}$ syringe filter (Lasec), followed by filtration through a $0.22 \mu \mathrm{m}$ syringe filter. The pre-cultured bacteria included 19 L. plantarum and 23 O. oeni strains and were inoculated at $1.5 \%(\mathrm{v} / \mathrm{v})$ (approximately $10^{6} \mathrm{CFU} / \mathrm{mL}$ ) in the synthetic wine medium and incubated at $20-22^{\circ} \mathrm{C}$ under static anaerobic conditions to undergo MLF. Cell counts were monitored at three different stages during MLF by conducting plate counts on MRS and MRST agar plates that were anaerobically incubated at $30^{\circ} \mathrm{C}$. The malic acid concentration was determined with a malic acid enzymatic assay (Roche, Boehringer Mannheim, Germany) on day seven of MLF.

\section{Molecular detection of genes involved in biogenic amine production \\ DNA preparation}

For DNA preparation purposes, the L. plantarum and O. oeni strains were grown at $30^{\circ} \mathrm{C}$ in MRS or MRSA broth, respectively, supplemented with $1.5 \%(\mathrm{w} / \mathrm{v})$ glycine (Saarchem, Merck) for 24 hours prior to isolation. The genomic DNA from L. plantarum and O. oeni strains were isolated as described by Lewington et al. (1987). The DNA samples were stored at $-20^{\circ} \mathrm{C}$. The quantification of DNA was performed spectrophotometrically using a NanoDrop ${ }^{\circledR}$ ND1000 (NanoDrop Technologies, Inc., Wilmington, USA).

\section{Genetic screening for enzyme-encoding genes using PCR}

Lactobacillus plantarum and $O$. oeni strains that showed potential in the synthetic wine medium were screened for the genes that encode for the histidine- (HDC), tyrosine- (TDC) and ornithine decarboxylase (ODC) enzymes. This was done with a multiplex-PCR method described by Marcobal et al. (2005). The primer sets for the decarboxylase genes can be seen in Table 2 . The $50 \mu \mathrm{L}$ reaction mixture contained $100 \mathrm{ng}$ template DNA, $0.3 \mu \mathrm{M}$ of primer set JV16HC/JV17HC (Whitehead Scientific, South Africa), $1 \mu \mathrm{M}$ of primer set $3 / 16$ and $2 \mu \mathrm{M}$ of primer set P1-rev/P2-for, $200 \mu \mathrm{M}$ dNTP's (Takara, Separations), $1.75 \mu \mathrm{M} \mathrm{MgCl}_{2}$ (Supertherm, Southern Cross Biotechnology), 1x PCR buffer (Supertherm, Southern Cross Biotechnology) and 1.5 U DNA Polymerase (Supertherm, Southern Cross Biotechnology).

Lactobacillus 30a (histamine- and putrescine-producing LAB strain) and Lactobacillus brevis M58 (tyramine producing LAB strain) were selected as positive controls in this PCR reaction (Downing, 2003; Marcobal et al., 2005). A negative control containing no bacterial DNA template was included in the PCR reaction. The PCR reaction conditions were as described in Table 3. All PCR reactions were done using a T3 Thermocycler (Whatman Biometra GmbH, Germany). The PCR products were analysed by gel electrophoresis in $1.5 \%(\mathrm{w} / \mathrm{v})$ agarose (Whitehead Scientific) gels containing $0.2 \mu \mathrm{g} / \mathrm{mL}$ ethidium bromide (Sigma-Aldrich). Gels were run at $85 \mathrm{~V}$ in a $1 \mathrm{x}$ TAE buffer (100 mM Tris-Cl, $1 \mathrm{mM}$ EDTA, pH 8, $20 \mathrm{mM}$ acetate) for approximately $45 \mathrm{~min}$. Ultraviolet transillumination was used for visualising DNA fragments and an Alpha Imager (Alpha Innotech Corporation, San Leandro, California) used for documenting the image. Lambda DNA (Roche) digested with BstE II (Roche) was used as the standard molecular weight marker.

Potential starter strains that were able to degrade malic acid in the synthetic wine medium and did not possess any of the genes associated with biogenic amine formation were genetically screened for the presence of enzymes associated with alteration of the sensory profile during MLF, including the production of volatile sulphur compounds, as well as the potential production of ethyl carbamate. The enzymes of interest that were screened for with PCR and gene-specific primers are listed in Table 2. The PCR reactions were carried out using isolated genomic DNA or a single bacterial colony as DNA template. A negative control contained no bacterial template. The gene-specific primer sets for $O$. oeni and/or L. plantarum and their applications are listed in Table 2 . 


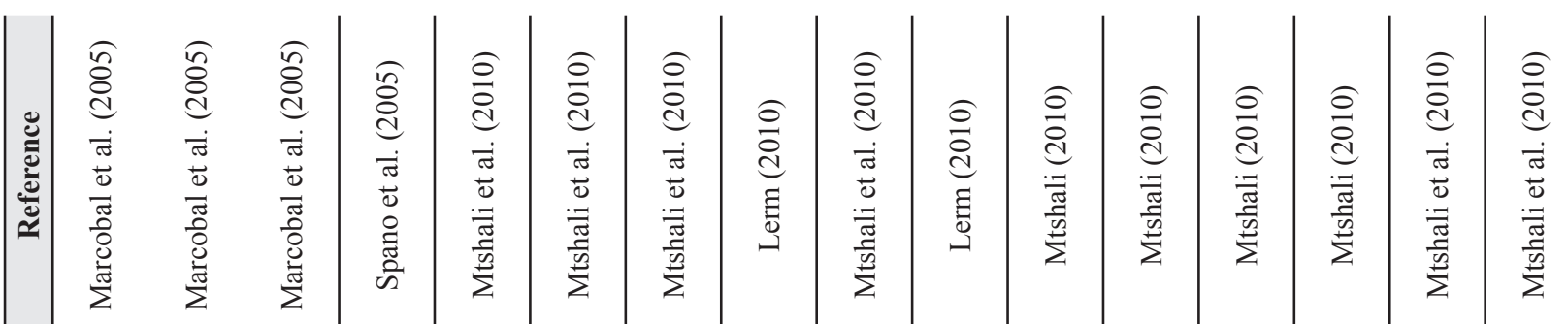

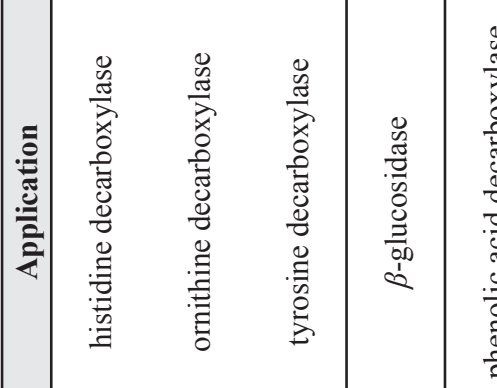

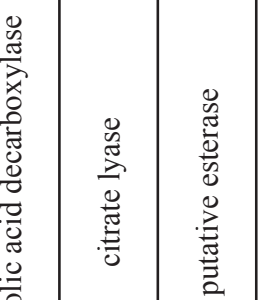

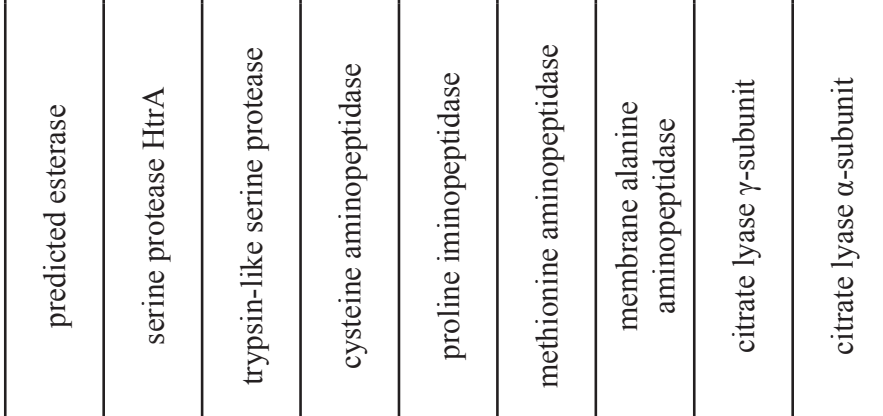

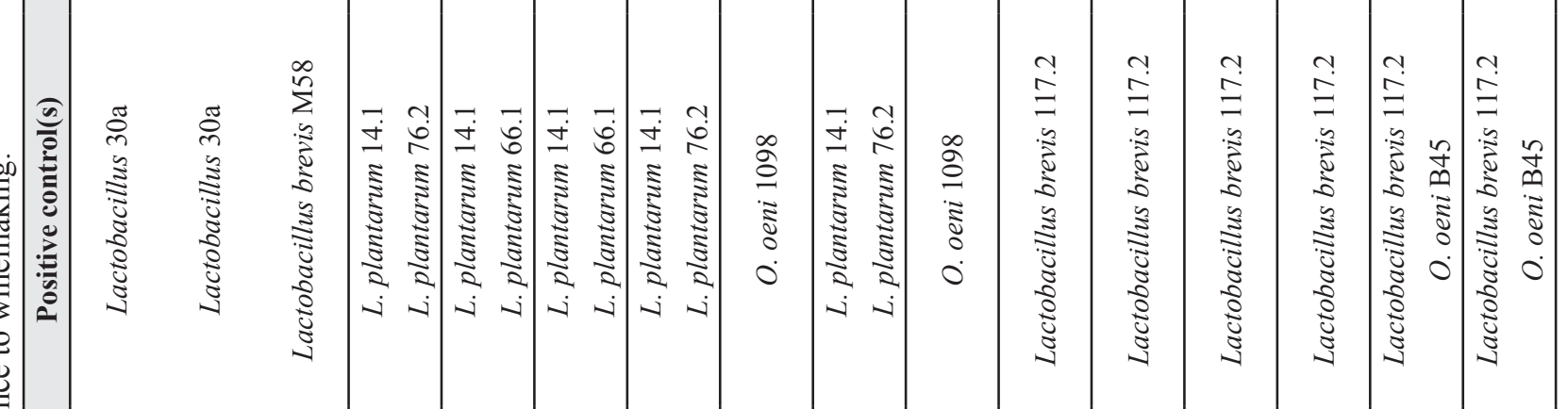

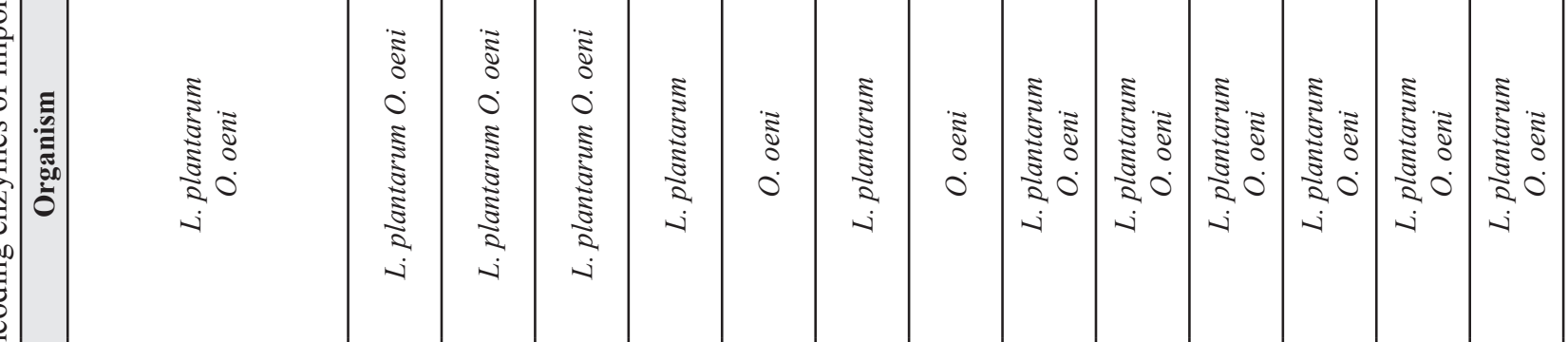

崖

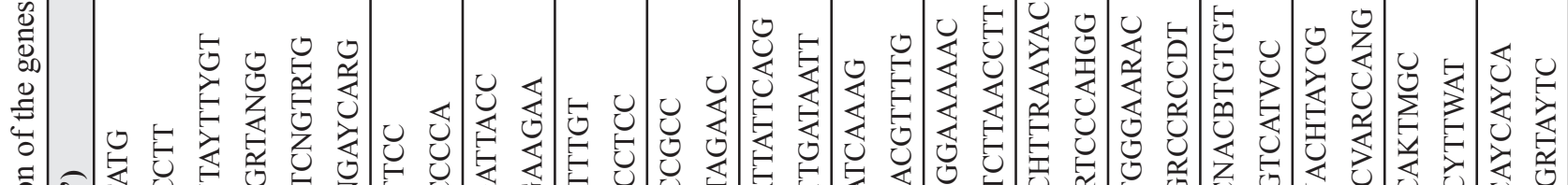

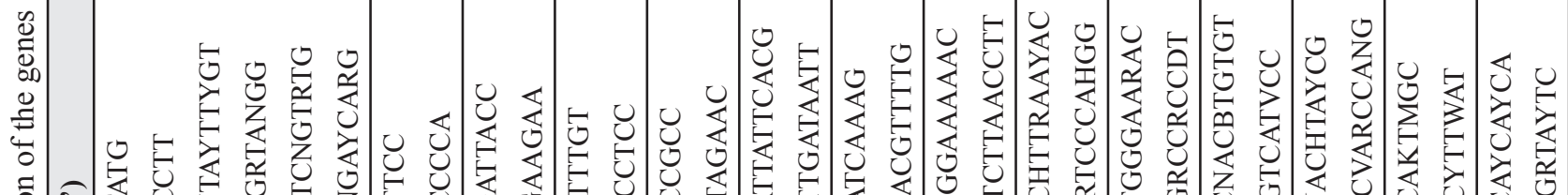
全涂

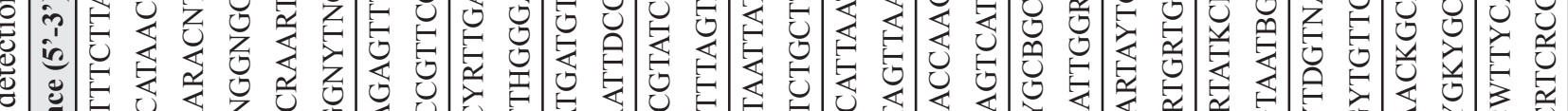
可

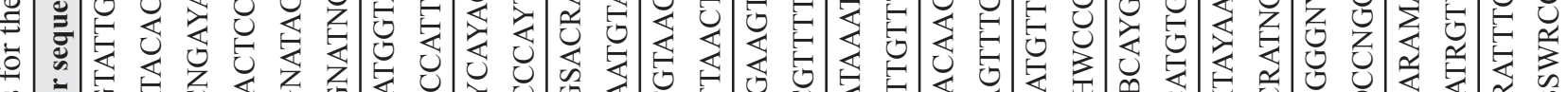

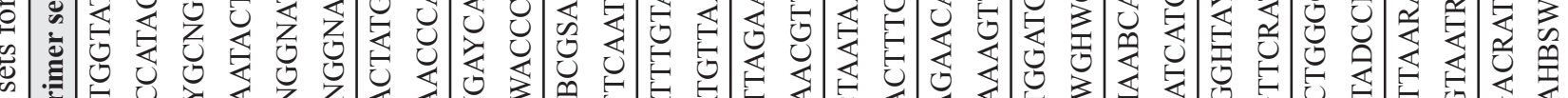
产焉

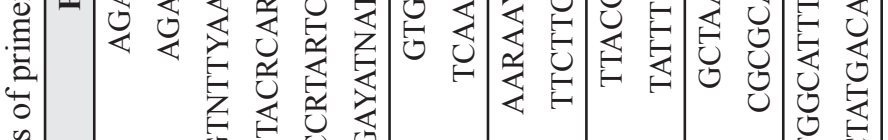

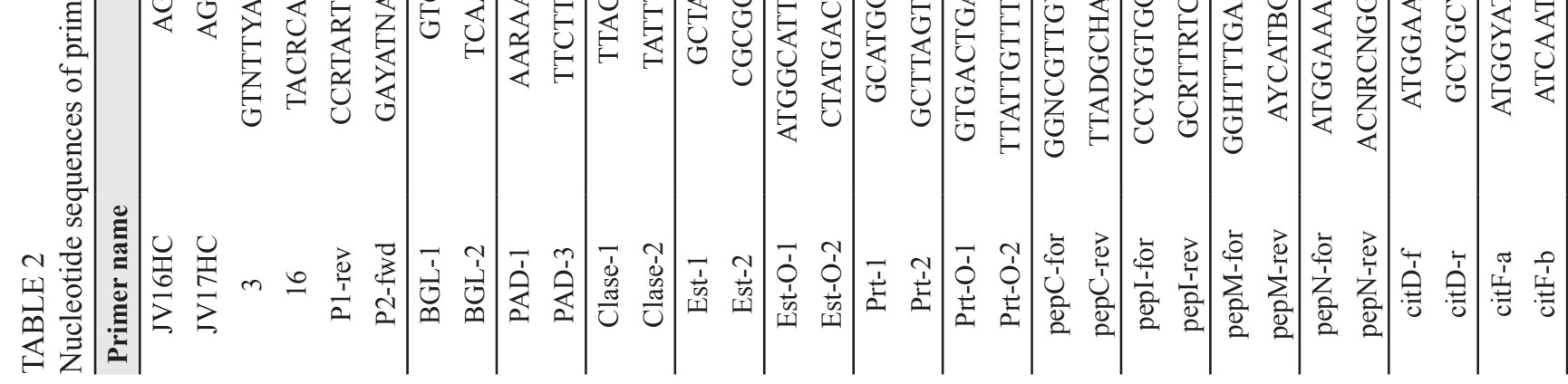




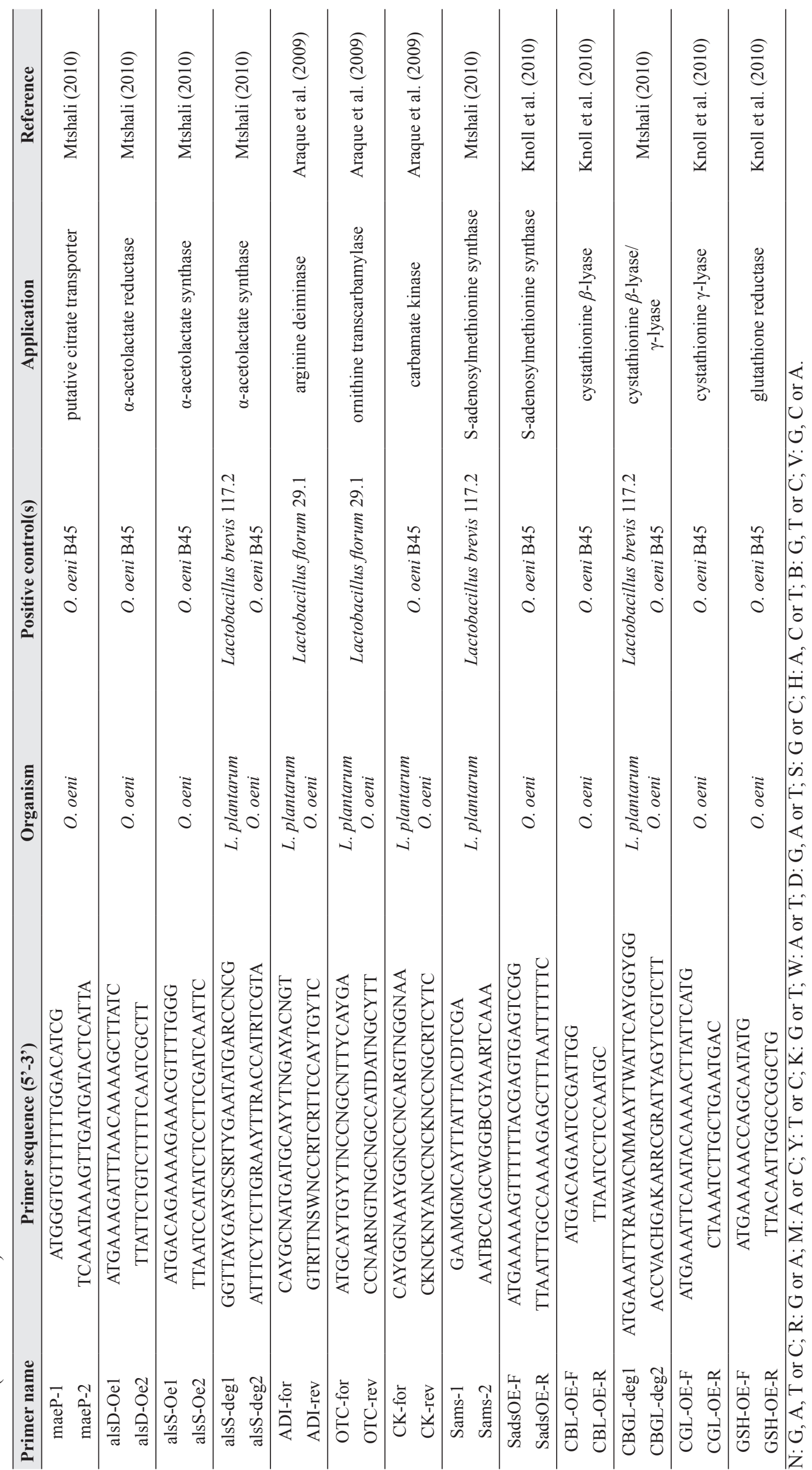




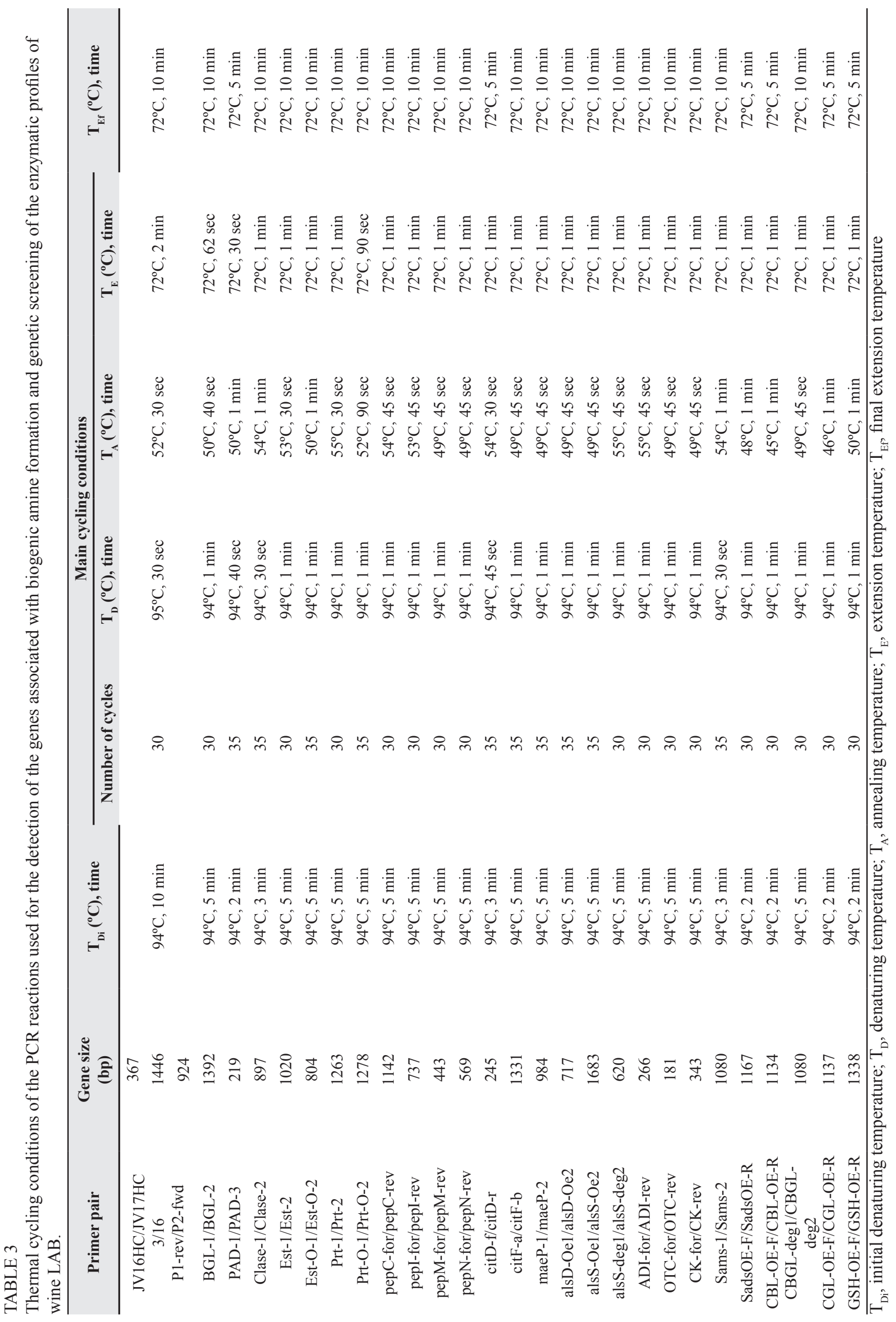


The PCR reaction mixtures are listed in Table 4. All PCR reactions were done as previously described. The PCR products were analysed by gel electrophoresis in 1 to $3 \%$ $(\mathrm{w} / \mathrm{v})$ agarose (Whitehead Scientific) gels containing $0.5 \mathrm{x}$ GelRed (Biotium). Gels were run at $80 \mathrm{~V}$ in a $1 \mathrm{x}$ TAE buffer (100 mM Tris-Cl, $1 \mathrm{mM}$ EDTA, pH 8, $20 \mathrm{mM}$ acetate) for approximately 45-60 minutes. Visualisation of the DNA fragments was as previously described. A 100 bp DNA Molecular Weight Marker XIV (Roche) was used as the standard molecular weight marker.

\section{Small-scale vinification procedures Alcoholic fermentation procedures}

Vinifications were conducted in Pinotage sourced from the Wellington region, South Africa. Half a ton of grapes were crushed and destemmed. Before the onset of AF, representative homogenous samples of the grape must were taken to determine the standard must parameters. Sulphur dioxide was added to the must at a concentration of $30 \mathrm{mg} / \mathrm{L}$ before the onset of AF to inhibit the growth of indigenous microflora. Lysozyme (DSM Food Specialties, Oenology, France) was added at $0.25 \mathrm{~g} / \mathrm{L}$ to inhibit indigenous LAB. The grape must was inoculated for batch $\mathrm{AF}$ with a commercial strain of Saccharomyces cerevisiae, WE372 (Anchor Yeast). Rehydration of the yeast strain was performed according to the manufacturer's specifications. Alcoholic fermentation of the grape must took place in contact with the grape skins. The decrease in sugar levels was measured on a daily basis using a Brix hydrometer to monitor the progression of AF. Alcoholic fermentation took place at $25^{\circ} \mathrm{C}$ and the skins were mixed with the juice on a daily basis using a manual punchdown method. Forty-eight hours after yeast inoculation, Nutrivin (Anchor Yeast), a nutrient supplement, was added at $70 \mathrm{~g} / \mathrm{hL}$. This provided a nutrient source for the yeast to avoid stuck or sluggish AF. After the completion of AF (less than $1 \mathrm{~g} / \mathrm{L}$ residual sugar) the wines were pressed with a hydraulic basket press and divided into $2 \mathrm{~L}$ glass bottles (sealed with airlocks) to complete spontaneous or induced MLF at $20^{\circ} \mathrm{C}$.

\section{Malolactic fermentation procedures}

The individual $O$. oeni and L. plantarum cultures were evaluated in duplicate in Pinotage (Table 5). The cultures were inoculated after the completion of $\mathrm{AF}$, referred to as sequential inoculation. An $O$. oeni commercial malolactic starter culture, Lalvin VP41® (Lallemand) was used as control fermentation. A treatment receiving no inoculation was used as a spontaneous fermentation control. The commercial MLF starter culture used during the small-scale vinifications was inoculated according to the instructions of the manufacturer at the recommended maximum dosage. All MLF treatments received a nutrient supplement, Optimalo'Plus (Lallemand), at a dosage of $20 \mathrm{~g} / \mathrm{hL} 48 \mathrm{~h}$ after inoculation of the bacterial culture.

After the completion of MLF, the wines were removed from the yeast lees and $\mathrm{SO}_{2}$ was added to all wines prior to bottling to achieve a total $\mathrm{SO}_{2}$ concentration of $80 \mathrm{mg} / \mathrm{L}$.

\section{Standard wine analysis}

Determination of the standard parameters of the juice and wine were performed with a WineScan FT120 spectrophotometer (FOSS Analytical, Denmark) (according to the method described by Louw et al., 2009). Duplicate scans were obtained for each sample. The standard parameters determined for the juice include: $\mathrm{pH}$, volatile- and total acid concentration, reducing sugars, malic acid concentration, glucose and fructose concentration and density. Wine parameters include: $\mathrm{pH}$, volatile- and total acidity, malic-

TABLE 4

PCR mixtures for the genetic detection of genes that encode for aroma- and wholesomeness-related enzymes in LAB.

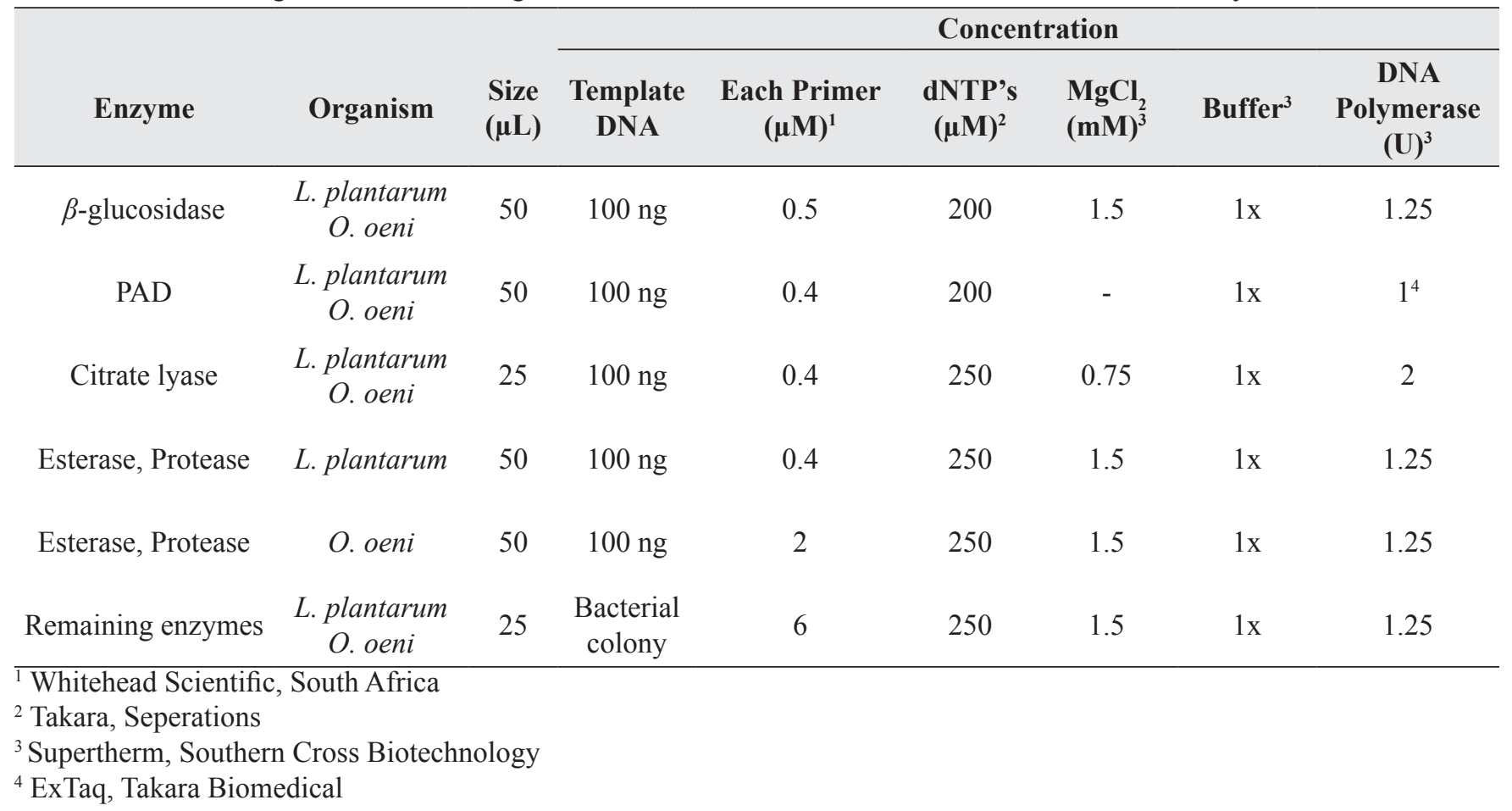


TABLE 5

The malic acid concentration measured after seven days in the synthetic wine medium inoculated with the different LAB strains. The synthetic wine medium contained an initial malic acid concentration of $3.5 \mathrm{~g} / \mathrm{L}$.

\begin{tabular}{|c|c|c|c|}
\hline LAB & Malic acid (g/L) & $\mathbf{L A B}$ & Malic acid (g/L) \\
\hline O. oеni B69 & 1.08 & L. plantarum 2.1 & 0.71 \\
\hline O. оепі D59 & 0.73 & L. plantarum 14 & 0.83 \\
\hline O. оепі D60 & 0.28 & L. plantarum $14.1 *$ & 0.00 \\
\hline O. oeni $\mathrm{E} 53 *$ & 0.28 & L. plantarum $56 *$ & 0.00 \\
\hline O. оепі $\mathrm{J} 65 *$ & 0.81 & L. plantarum 65 & 1.32 \\
\hline O. oeni M69 & 1.08 & L. plantarum $66.1 *$ & 0.27 \\
\hline O. oeni $\mathrm{N} 73$ & 1.10 & L. plantarum $68 *$ & 0.02 \\
\hline O. oеni W56 & 1.09 & L. plantarum 69 & 0.17 \\
\hline O. oеni W75 & 1.11 & L. plantarum 70 & 0.08 \\
\hline O. oеni W77 & 0.98 & L. plantarum 71 & 0.72 \\
\hline O. oeni A1 & 0.98 & L. plantarum $71.1 *$ & 0.17 \\
\hline O. oеni A $2 *$ & 0.58 & L. plantarum 73.1 & 0.41 \\
\hline O. oеni B1 * & 0.49 & L. plantarum 75 & 1.08 \\
\hline O. oеni $\mathrm{C} 1$ & 1.26 & L. plantarum 76.2 & 0.53 \\
\hline O. oeni $\mathrm{S} 1$ & 0.49 & L. plantarum 77.1 & 1.10 \\
\hline O. oeni $\mathrm{S} 2$ & 0.35 & L. plantarum $78.1 *$ & 0.24 \\
\hline O. oeni $\mathrm{S} 3$ & 0.95 & L. plantarum 80.2 & 1.04 \\
\hline O. oeni $\mathrm{S} 4$ & 0.28 & L. plantarum 107 * & 0.05 \\
\hline O. oeni S5* & 0.25 & L. plantarum 109 & 0.65 \\
\hline O. оепi $\mathrm{S} 6$ * & 0.32 & & \\
\hline O. oеni S7 & 0.55 & & \\
\hline O. oеni $\mathrm{S} 8$ & 0.40 & & \\
\hline O. oеni $\mathrm{S} 9$ & 1.05 & & \\
\hline
\end{tabular}

* strains selected for evaluation in Pinotage

and lactic acid, glucose and fructose, ethanol and glycerol. Sulphur dioxide (total and free) analysis was carried out using the Metrohm titration unit (Metrohm Ltd., Switzerland). Malolactic fermentation in the wine was monitored by obtaining the malic- and lactic acid concentrations on a regular basis (at the start of MLF and every seven days thereafter) until its completion (taken as the point when the malic acid concentration is equal to or lower than $0.3 \mathrm{~g} / \mathrm{L}$ ). This was done by Fourier-transform Infrared Spectroscopy (FT-IR) (WineScan FT120, FOSS Analytical, Denmark) as well as determination of the malic acid concentration with an enzymatic assay (Roche, Boehringer Mannheim, Germany).

\section{RESULTS}

\section{Screening in synthetic wine medium}

Nineteen L. plantarum and 23 O. oeni strains were identified and selected for evaluation in the synthetic wine medium. The screening process in the synthetic wine medium was used as an indication of the possible survival and performance of the potential starter strains in the actual wine environment. Table 5 lists the LAB strains and the corresponding malic acid concentrations measured in the synthetic wine medium after seven days of MLF at $20-22^{\circ} \mathrm{C}$. The L. plantarum strains performed the best and nine of the strains were able to convert the initial malic acid concentration of $3.5 \mathrm{~g} / \mathrm{L}$ to below $0.3 \mathrm{~g} / \mathrm{L}$ in seven days. Seven $O$. oeni and seven
L. plantarum strains that showed potential in the synthetic medium were selected for further characterisation. Selection was not only based on the performance of the potential starter strains in the synthetic wine medium with regards to malic acid degradation, but also the ability of the strains to proliferate and maintain sufficient population numbers during the completion of MLF (these strains are highlighted in Table 6).

\section{Genes involved in biogenic amine production}

The seven $L$. plantarum and seven $O$. oeni strains that successfully degraded malic acid or displayed potential in the synthetic medium, were screened for the genes that encode for the amino acid decarboxylase enzymes responsible for biogenic amine formation. The primers amplified single products of $367 \mathrm{bp}$ and $1446 \mathrm{bp}$ for Lactobacillus 30a, corresponding to fragments of the $h d c$ and odc genes, respectively and a product of $924 \mathrm{bp}$ for Lactobacillus brevis M58, corresponding to a fragment of the $t d c$ gene. Of the 14 selected strains that were screened (results not shown), none of the strains contained $h d c, o d c$ or $t d c$ gene fragments.

\section{PCR detection of genes encoding enzymes of enological interest}

Genetic screenings of the enzyme-encoding genes were done for the 14 selected LAB strains that were negative for the genes 
TABLE 6

Cell counts $(\mathrm{CFU} / \mathrm{mL})$ of the individual L. plantarum and O. oeni strains as recorded at the start and different stages of MLF in the synthetic wine medium.

\begin{tabular}{|c|c|c|c|c|c|c|c|c|c|}
\hline & & \multicolumn{3}{|c|}{ Days after inoculation } & & & \multicolumn{3}{|c|}{ Days after inoculation } \\
\hline & & $\mathbf{0}$ & 2 & 6 & & & $\mathbf{0}$ & 2 & 6 \\
\hline \multirow[t]{23}{*}{ L. plantarum } & 2.1 & $5.4 \times 10^{7}$ & $2.4 \times 10^{7}$ & $1.5 \times 10^{6}$ & \multirow[t]{3}{*}{ O. oeni } & B69 & $2.9 \times 10^{7}$ & $1.0 \times 10^{6}$ & $2.0 \times 10^{4}$ \\
\hline & 14 & $4.2 \times 10^{7}$ & $3.0 \times 10^{6}$ & $8.0 \times 10^{5}$ & & D59 & $1.0 \times 10^{5}$ & $1.0 \times 10^{5}$ & $1.0 \times 10^{4}$ \\
\hline & $14.1^{*}$ & $3.5 \times 10^{7}$ & $1.3 \times 10^{7}$ & $6.2 \times 10^{6}$ & & D60 & $4.3 \times 10^{8}$ & $7.0 \times 10^{7}$ & $1.0 \times 10^{7}$ \\
\hline & $56^{*}$ & $4.7 \times 10^{7}$ & $1.5 \times 10^{7}$ & $2.0 \times 10^{6}$ & & E53* & $1.9 \times 10^{8}$ & $3.4 \times 10^{7}$ & $7.0 \times 10^{5}$ \\
\hline & 65 & $8.3 \times 10^{6}$ & $4.0 \times 10^{5}$ & $2.4 \times 10^{5}$ & & $\mathrm{~J} 65^{*}$ & $2.6 \times 10^{8}$ & $5.3 \times 10^{7}$ & $5.0 \times 10^{6}$ \\
\hline & $66.1^{*}$ & $5.5 \times 10^{7}$ & $2.5 \times 10^{7}$ & $9.9 \times 10^{5}$ & & M69 & $3.0 \times 10^{8}$ & $5.0 \times 10^{7}$ & $5.0 \times 10^{6}$ \\
\hline & $68^{*}$ & $3.6 \times 10^{7}$ & $1.7 \times 10^{7}$ & $2.9 \times 10^{6}$ & & N73 & $1.2 \times 10^{7}$ & $1.0 \times 10^{6}$ & $3.0 \times 10^{4}$ \\
\hline & 69 & $4.6 \times 10^{7}$ & $2.7 \times 10^{7}$ & $1.3 \times 10^{6}$ & & W56 & $4.7 \times 10^{7}$ & $7.0 \times 10^{7}$ & $1.0 \times 10^{6}$ \\
\hline & 70 & $3.6 \times 10^{7}$ & $1.0 \times 10^{7}$ & $3.0 \times 10^{6}$ & & W75 & $1.1 \times 10^{5}$ & $1.0 \times 10^{5}$ & $1.0 \times 10^{4}$ \\
\hline & 71 & $2.2 \times 10^{7}$ & $3.2 \times 10^{6}$ & $9.0 \times 105$ & & W77 & $1.0 \times 10^{5}$ & $1.0 \times 10^{5}$ & $1.0 \times 10^{4}$ \\
\hline & $71.1^{*}$ & $4.4 \times 10^{7}$ & $4.7 \times 10^{6}$ & $2.3 \times 10^{6}$ & & A1 & $8.1 \times 10^{7}$ & $8.0 \times 10^{7}$ & $6.9 \times 10^{6}$ \\
\hline & 73.1 & $4.0 \times 10^{7}$ & $9.9 \times 10^{6}$ & $7.5 \times 10^{6}$ & & $\mathrm{~A} 2 *$ & $9.0 \times 10^{7}$ & $7.9 \times 10^{7}$ & $1.0 \times 10^{6}$ \\
\hline & 75 & $3.0 \times 10^{6}$ & $1.2 \times 10^{6}$ & $5.9 \times 10^{5}$ & & $\mathrm{~B} 1 *$ & $2.8 \times 10^{8}$ & $1.5 \times 10^{8}$ & $1.0 \times 10^{5}$ \\
\hline & 76.2 & $6.2 \times 10^{7}$ & $2.2 \times 10^{7}$ & $5.4 \times 10^{6}$ & & $\mathrm{C} 1$ & $1.6 \times 10^{8}$ & $1.2 \times 10^{8}$ & $2.0 \times 10^{5}$ \\
\hline & 77.1 & $2.4 \times 10^{7}$ & $2.3 \times 10^{6}$ & $1.4 \times 10^{6}$ & & $\mathrm{~S} 1$ & $1.5 \times 10^{8}$ & $8.6 \times 10^{7}$ & $7.5 \times 10^{5}$ \\
\hline & $78.1^{*}$ & $3.6 \times 10^{7}$ & $9.4 \times 10^{6}$ & $1.9 \times 10^{6}$ & & $\mathrm{~S} 2$ & $1.5 \times 10^{8}$ & $1.3 \times 10^{8}$ & $5.0 \times 10^{5}$ \\
\hline & 80.2 & $3.6 \times 10^{7}$ & $3.6 \times 10^{6}$ & $2.9 \times 10^{6}$ & & S3 & $2.0 \times 10^{8}$ & $1.5 \times 10^{8}$ & $3.0 \times 10^{5}$ \\
\hline & $107 *$ & $5.8 \times 10^{7}$ & $2.2 \times 10^{6}$ & $4.2 \times 10^{4}$ & & S4 & $2.6 \times 10^{8}$ & $1.3 \times 10^{8}$ & $1.0 \times 10^{5}$ \\
\hline & \multirow[t]{5}{*}{109} & \multirow[t]{5}{*}{$3.3 \times 10^{7}$} & \multirow{5}{*}{$1.4 \times 10^{7}$} & \multirow[t]{5}{*}{$2.6 \times 10^{6}$} & & S5* & $4.8 \times 10^{7}$ & $3.3 \times 10^{8}$ & $8.0 \times 10^{5}$ \\
\hline & & & & & & S6* & $5.0 \times 10^{7}$ & $2.0 \times 10^{7}$ & $9.0 \times 10^{5}$ \\
\hline & & & & & & S7 & $1.7 \times 10^{8}$ & $1.2 \times 10^{8}$ & $3.0 \times 10^{5}$ \\
\hline & & & & & & S8 & $1.0 \times 10^{8}$ & $9.6 \times 10^{7}$ & $4.0 \times 10^{5}$ \\
\hline & & & & & & S9 & $1.7 \times 10^{8}$ & $1.2 \times 10^{8}$ & $2.0 \times 10^{5}$ \\
\hline
\end{tabular}

* strains selected for evaluation in Pinotage

associated with biogenic amine formation. The enzymes of interest that were screened for and could potentially influence the aroma profile, included $\beta$-glucosidase, PAD, citrate lyase, esterase, protease, peptidases and enzymes related to the production of volatile sulphur compounds. Other enzymes of interest included those that play a role in the production of ethyl carbamate. The results of the genetic screening of the enzymes for L. plantarum and O. oeni are shown in Tables 7 and 8 , respectively.

\section{Malolactic fermentation}

\section{Must and wine composition before inoculation}

The chemical composition of the Pinotage grape must utilised for evaluation of the cultures were as follow (concentrations indicated in brackets): total sugar $(309 \mathrm{~g} / \mathrm{L})$, malic acid $(1.79 \mathrm{~g} / \mathrm{L})$, total acid $(5.72 \mathrm{~g} / \mathrm{L})$ and $\mathrm{pH}$ 3.97. The standard wine parameters after AF and before inoculation for MLF were as follow: $\mathrm{pH} 3.89$, volatile acidity $(0.45 \mathrm{~g} / \mathrm{L})$, total acidity $(5.28 \mathrm{~g} / \mathrm{L})$, malic acid $(1.76 \mathrm{~g} / \mathrm{L})$, lactic acid $(0 \mathrm{~g} / \mathrm{L})$ and ethanol $(15.82 \% \mathrm{v} / \mathrm{v})$. The wine was fermented until the residual sugar concentration was determined as being less than $1 \mathrm{~g} / \mathrm{L}$. The Pinotage grapes were harvested at a very high sugar level which resulted in a high alcohol concentration.

\section{Evaluation of fermentation capability}

The isolates that were able to degrade malic acid in the synthetic wine medium, were able to maintain sufficient population numbers and were able to proliferate in the adaptation medium prior to inoculation in the wine, were selected for evaluation in Pinotage (Table 5). The commercial culture Lalvin VP41® (Lallemand) was included to compare the fermentation performance of the selected LAB strains with that of a commercial product. By monitoring a spontaneous fermentation control receiving no inoculation, this could provide an indication of the contribution of the indigenous $\mathrm{LAB}$ population to the fermentation process.

Of the seven L. plantarum strains that were evaluated, only three completed MLF (Fig. 1), while the remaining four strains did not complete MLF. The three strains were L. plantarum 14.1, 56 and 107. The control O. oeni culture VP41 showed the best performance and completed the fermentation in 23 days. Of the best performing L. plantarum strains, L. plantarum 107 finished MLF in 30 days, compared to strains 56 and 14.1 which required 44 days. Despite the fact that L. plantarum 107 cell counts showed the most drastic decrease over the course of the fermentation (Table 9), a faster fermentation rate was evident. The spontaneous fermentation never completed MLF. Microbiological analysis (Table 9) showed that all 
the treatments were inoculated at approximately $2 \times 10^{6}$ to $4 \times 10^{6} \mathrm{CFU} / \mathrm{mL}$. Lactobacillus plantarum cell counts stayed constant or showed a slight decrease over the initial fermentation period, followed by a steady decline towards the end of fermentation. Cell counts of VP41 stayed constant over the course of the fermentation. Cell numbers eventually decreased to approximately $10^{4} \mathrm{CFU} / \mathrm{mL}$ after the completion of MLF.

Oenococcus oeni W56 displayed diminished growth on the agar medium, in broth and the adaptation medium, compared to the other strains. For this reason, $O$. oeni W56 was not included in the evaluations of the strains in Pinotage. Four of the six $O$. oeni strains were able to complete MLF (Fig. 2). These four O. oeni isolates, S5, S6, J65 and E53, completed MLF in nine days, showing a faster fermentation rate than VP41, which took 16 days to complete fermentation. Microbiological analysis showed that the $O$. oen $i$ isolates were inoculated at approximately
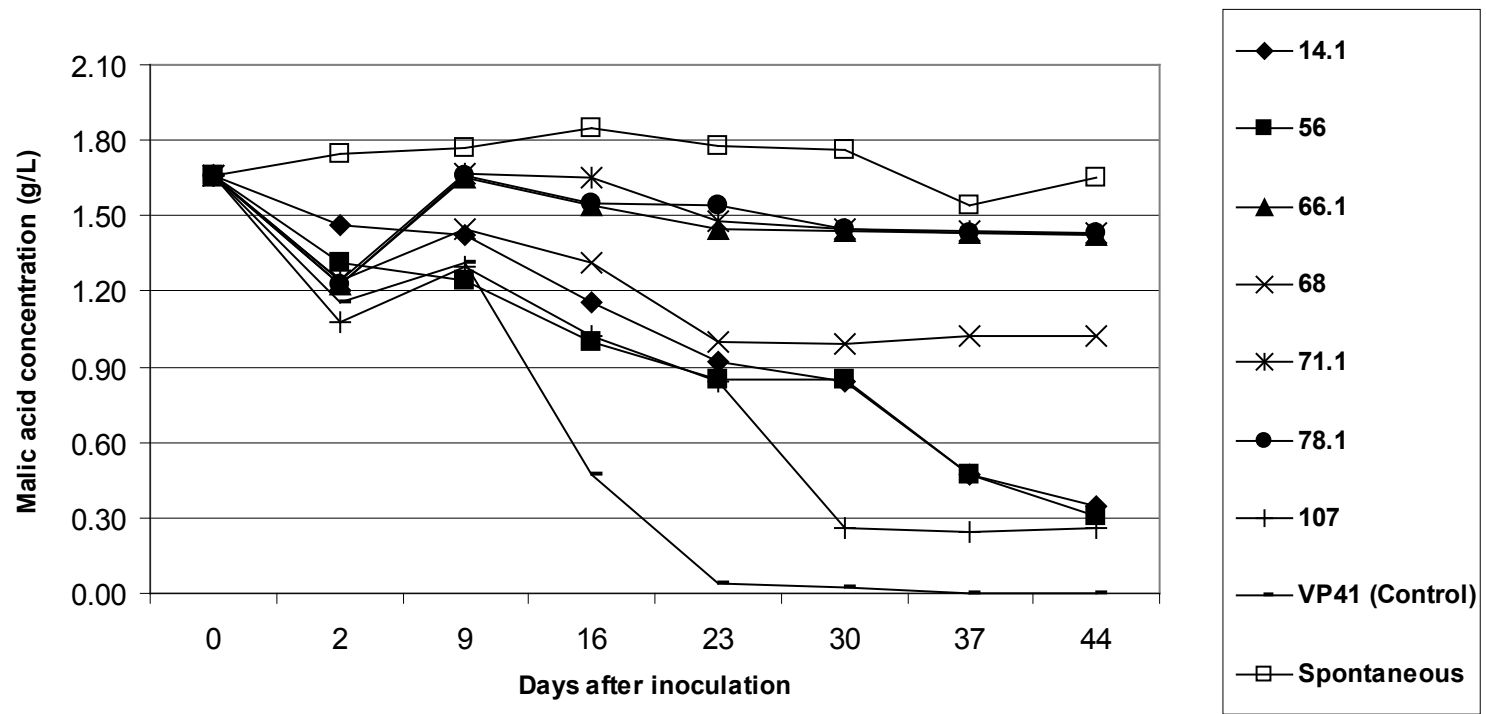

FIGURE 1

A fermentation graph showing the evolution of malic acid $(\mathrm{g} / \mathrm{L})$ in the MLF treatments evaluating the individual L. plantarum strains in Pinotage. Fermentations were monitored from the start of MLF on a weekly basis. Data shown indicate the average changes in the malic acid concentration $(\mathrm{g} / \mathrm{L})$ of each treatment repeated in duplicate. The relative standard deviation (RSD) is less than $10 \%$ between fermentation repeats.
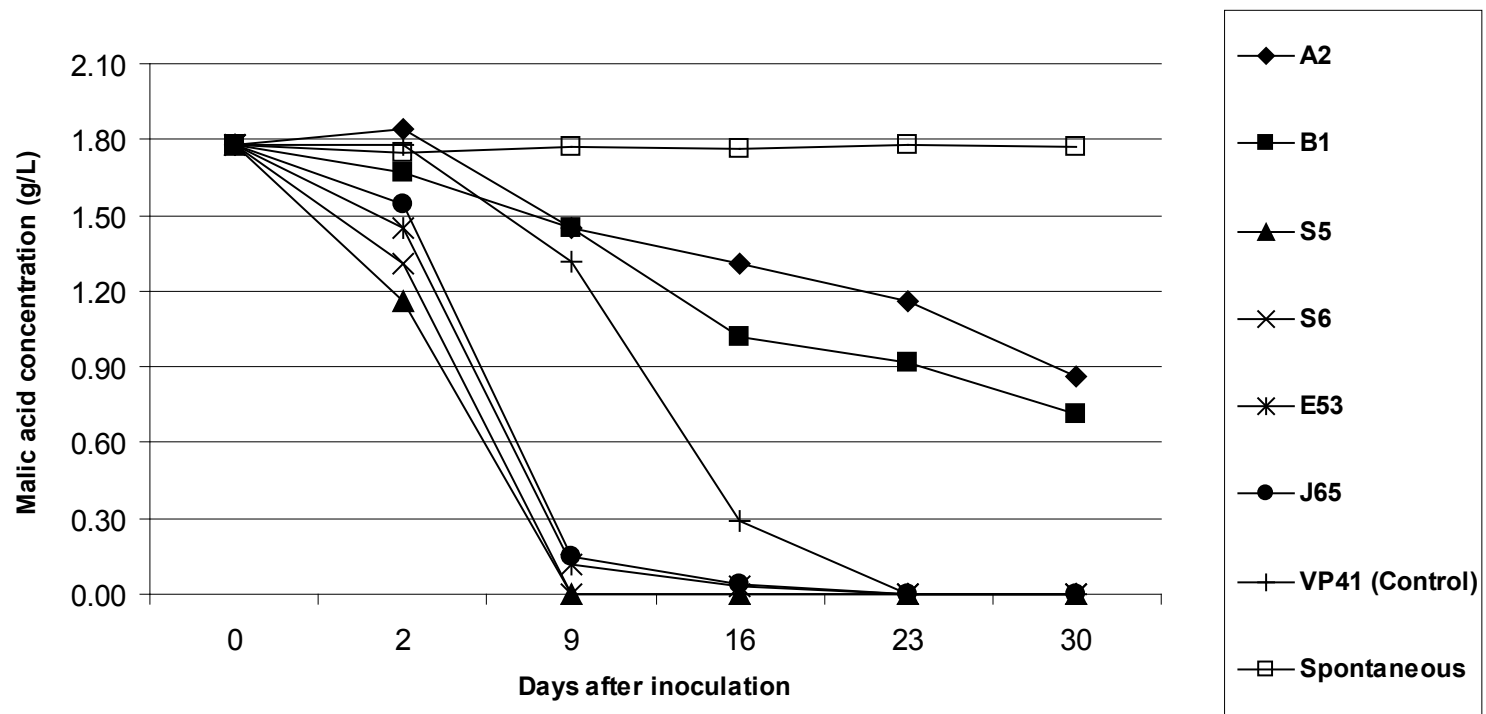

FIGURE 2

A fermentation graph showing the evolution of malic acid $(\mathrm{g} / \mathrm{L})$ in the MLF treatments evaluating the individual $O$. oeni strains in Pinotage. Fermentations were monitored from the start of MLF on a weekly basis. Data shown indicate the average changes in the malic acid concentration $(\mathrm{g} / \mathrm{L})$ of each treatment repeated in duplicate. The RSD is less than $10 \%$ between fermentation repeats. 
$10^{7} \mathrm{CFU} / \mathrm{mL}$ (Table 9) and VP41 at $2 \times 10^{6} \mathrm{CFU} / \mathrm{mL}$. This could be a possible contributing factor to the faster fermentation rate displayed by the isolates compared to that of the control culture. Cell counts stayed constant during the early stages of MLF and slightly increased over the course of the fermentation. Oenococcus oeni B1 and J65 were the only treatments of which the bacterial population decreased to $10^{6} \mathrm{CFU} / \mathrm{mL}$ at the end of fermentation.

None of the LAB isolates resulted in volatile acidity concentrations exceeding the sensory threshold value of $0.7 \mathrm{~g} / \mathrm{L}$ (Jackson, 2008) (results not shown). The seven L. plantarum strains showed similar final volatile acidity concentrations $( \pm 0.50 \mathrm{~g} / \mathrm{L})$. Oenococcus oeni strains A2, B1 and J65 displayed slightly lower volatile acidity concentrations $( \pm 0.48 \mathrm{~g} / \mathrm{L})$ compared to $O$. oeni $\mathrm{S} 5$, S6 and E53 (0.57 g/L).

\section{DISCUSSION}

This study focused on characterising O. oeni and L. plantarum strains for possible use in a MLF starter culture. Strains were first selected after characterisation in a synthetic wine matrix, which resulted in 13 potential MLF strains. These strains were then evaluated in wine which eliminated certain strains as they did not perform MLF satisfactorily. There are various other studies that also make use of synthetic or wine-like media for the characterisation of LAB strains. Capozzi et al. (2010) made use of two different wine-like media with 11 and $13 \%$ (v/v) ethanol, respectively. Despite the fact that their $O$. oeni strains were isolated from wines with 12.5 and $13.9 \%(\mathrm{v} / \mathrm{v})$ ethanol, the $O$. oeni strains were unable to survive in the $13 \%(\mathrm{v} / \mathrm{v})$ ethanol medium. These results are similar to our findings. The $O$. oeni strains seem to find higher ethanol concentrations in the synthetic wine medium to be more challenging, which is in direct contrast to their performance in wine. These findings are supported by Solieri et al. (2010), a study in which a lower ethanol concentration of $10 \%(\mathrm{v} / \mathrm{v})$ allowed the O. oeni strains to complete MLF. Potential limitations of the synthetic wine medium are the lack of phenolic compounds and specific nutrients needed for growth. The addition of these compounds is essential because wine LAB, particularly $O$. oeni, are generally inhibited by tannins and phenolic

\section{TABLE 7}

The results from the genetic screening of the enzymes of the L. plantarum strains. Presence of the gene is indicated with $(+)$ and absence of the gene is indicated with (-).

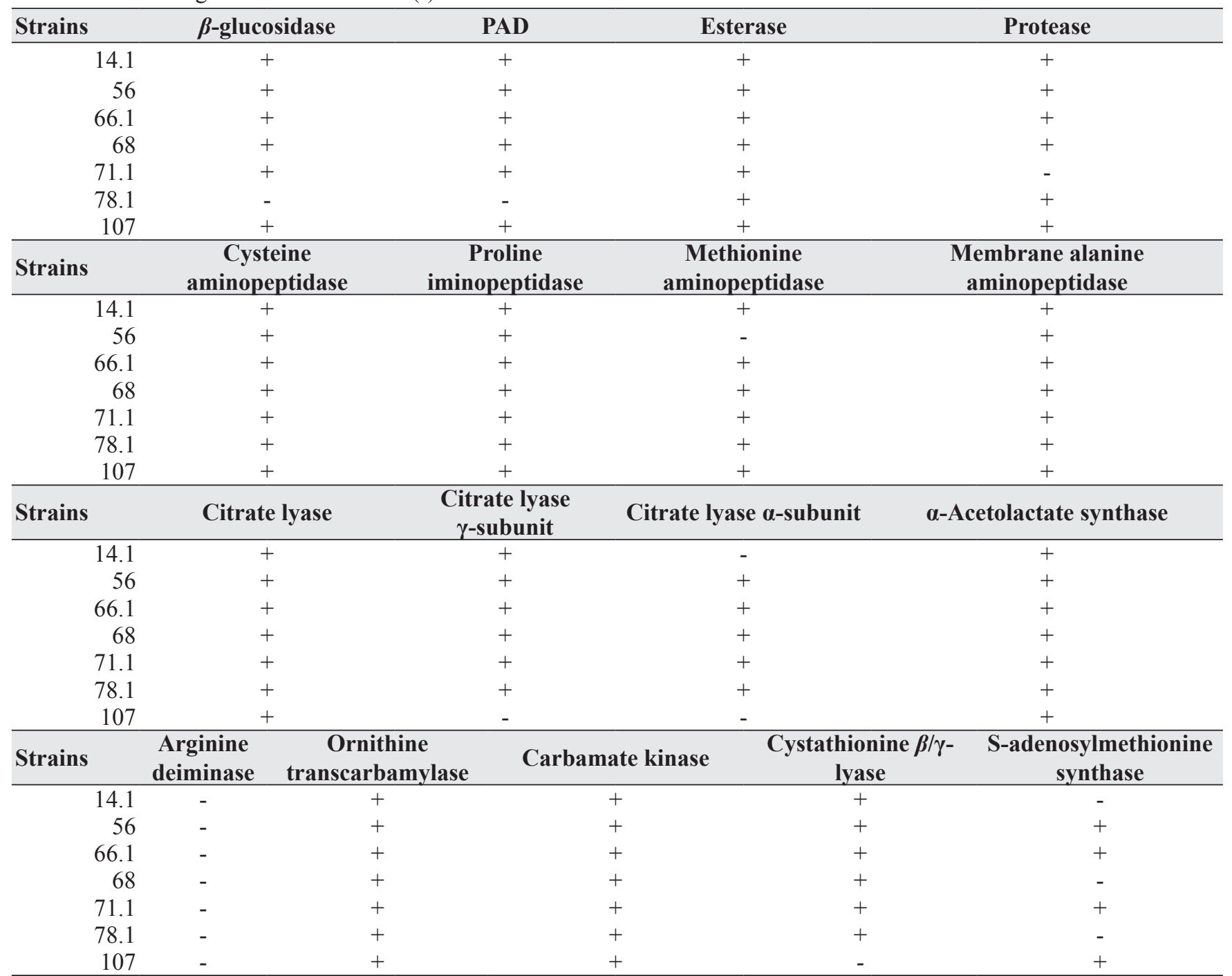


TABLE 8

The results from the genetic screening of the enzymes of the $O$. oeni strains. Presence of the gene is indicated with $(+)$ and absence of the gene is indicated with (-).

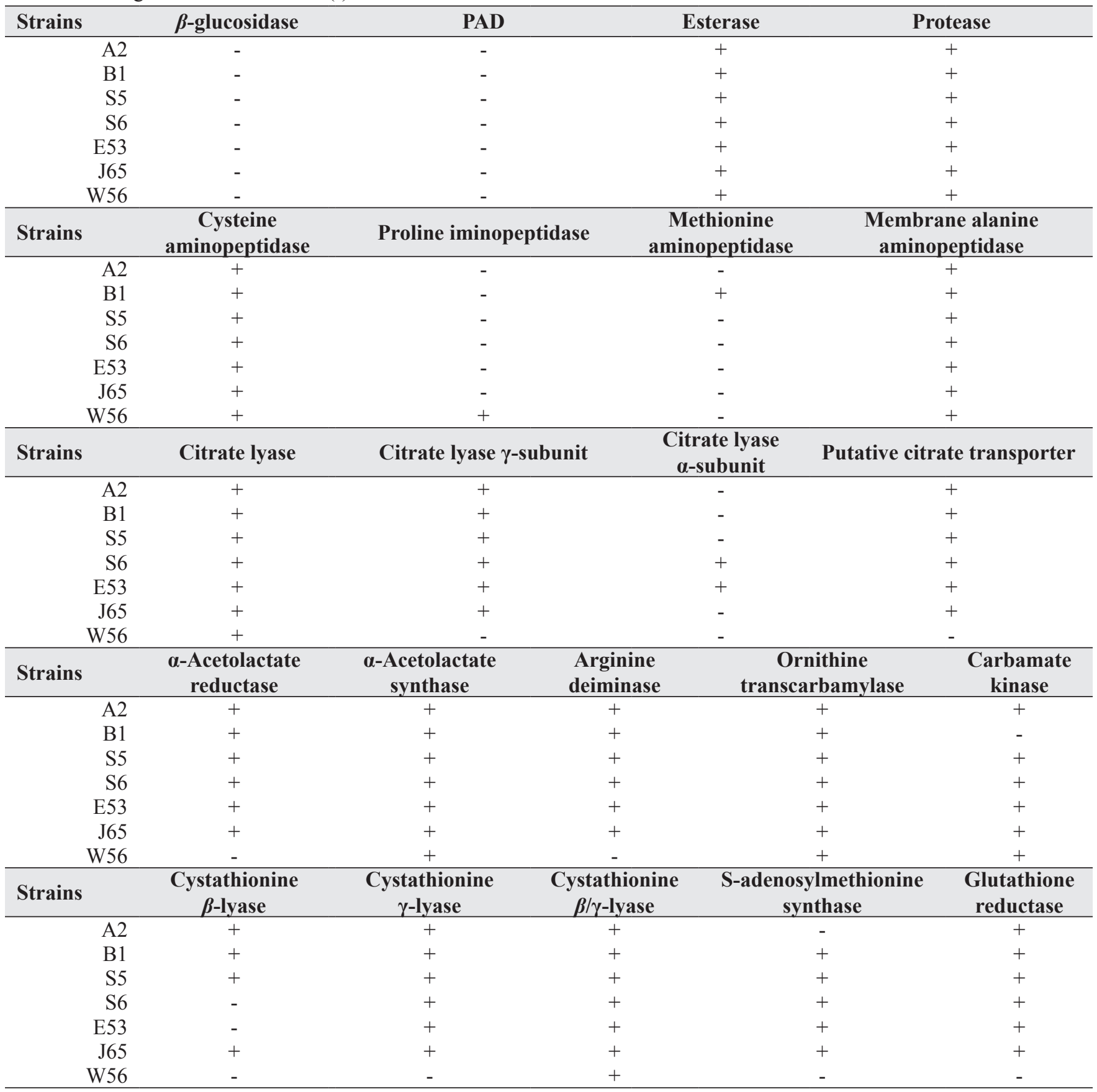

acids, while anthocyanins and gallic acid have a stimulatory effect on growth and malolactic activity (Vivas et al., 1997; Campos et al., 2003). It has been shown that strains of $O$. oeni and some strains of the Lactobacillus genera have essential nutrient requirements, particularly with regards to amino acids, but also vitamins and in the case of $O$. oeni, the so-called "tomato juice factor", a pantothenic acid derivative (Fugelsang \& Edwards, 1997; Terrade \& Mira de Orduña, 2009). These studies and our results highlight the need for a synthetic wine-like medium that better simulates the wine environment and could provide a more accurate indication of the malic acid degradation ability and survival of LAB strains in wine.
The inability to produce biogenic amines is an important characteristic for any strain being considered for use in a starter culture, as biogenic amines have an impact on wine wholesomeness, have several health implications as well as impacting wine aroma. Our results correlate with other studies, although results on $O$. oeni in literature vary. Oenococcus oeni has been identified as the main histamine producer (Moreno-Arribas et al., 2000) and 60\% of the $O$. oeni strains studied by Guerrini et al. (2002) were able to produce histamine, while Landete et al. (2005) found that although $O$. oen $i$ was the most frequent histamine producer, this species also produced the lowest concentrations and that this production is strain dependent (Rosi et al., 2009). In a 
TABLE 9

Cell counts $(\mathrm{CFU} / \mathrm{mL})$ of the individual LAB isolates and control fermentations as recorded at the start and different stages of MLF in Pinotage. Each enumeration represents the average of duplicate treatments (standard deviations not shown).

\begin{tabular}{|c|c|c|c|c|c|c|c|}
\hline & & \multicolumn{6}{|c|}{ Days after inoculation } \\
\hline & & $\mathbf{0}$ & 2 & 9 & 16 & 23 & 30 \\
\hline \multirow[t]{10}{*}{ L. plantarum } & 14.1 & $2.9 \times 10^{6}$ & $1.2 \times 10^{6}$ & $1.3 \times 10^{6}$ & $1.0 \times 10^{6}$ & $3.2 \times 10^{5}$ & $1.0 \times 10^{5}$ \\
\hline & 56 & $3.1 \times 10^{6}$ & $3.0 \times 10^{6}$ & $1.3 \times 10^{6}$ & $5.0 \times 10^{5}$ & $1.3 \times 10^{5}$ & $8.4 \times 10^{4}$ \\
\hline & 66.1 & $3.6 \times 10^{6}$ & $3.9 \times 10^{6}$ & $7.9 \times 10^{5}$ & $2.4 \times 10^{5}$ & $7.1 \times 10^{4}$ & $1.0 \times 10^{4}$ \\
\hline & 68 & $3.0 \times 10^{6}$ & $2.7 \times 10^{6}$ & $4.8 \times 10^{5}$ & $9.0 \times 10^{4}$ & $1.4 \times 10^{4}$ & $1.0 \times 10^{4}$ \\
\hline & 71.1 & $3.5 \times 10^{6}$ & $1.7 \times 10^{6}$ & $2.9 \times 10^{5}$ & $1.8 \times 10^{5}$ & $7.9 \times 10^{4}$ & $4.0 \times 10^{4}$ \\
\hline & 78.1 & $4.9 \times 10^{6}$ & $2.4 \times 10^{6}$ & $2.9 \times 10^{5}$ & $1.5 \times 10^{5}$ & $7.6 \times 10^{4}$ & $2.4 \times 10^{4}$ \\
\hline & 107 & $3.3 \times 10^{6}$ & $2.7 \times 10^{6}$ & $1.0 \times 10^{6}$ & $3.5 \times 10^{4}$ & $2.7 \times 10^{3}$ & $1.2 \times 10^{3}$ \\
\hline & VP41 & $3.2 \times 10^{6}$ & $1.3 \times 10^{6}$ & $1.0 \times 10^{6}$ & $1.2 \times 10^{6}$ & $2.8 \times 10^{6}$ & $4.3 \times 10^{6}$ \\
\hline & & \multicolumn{6}{|c|}{ Days after inoculation } \\
\hline & & $\mathbf{0}$ & & 2 & 9 & & 16 \\
\hline \multirow[t]{7}{*}{ O. oeni } & A2 & $2.3 \times 10^{7}$ & & $2.1 \times 10^{7}$ & $2.3 \times 10^{7}$ & & $1.2 \times 10^{7}$ \\
\hline & B1 & $2.5 \times 10^{7}$ & & $1.5 \times 10^{7}$ & $1.5 \times 10^{7}$ & & $8.9 \times 10^{6}$ \\
\hline & S5 & $1.9 \times 10^{7}$ & & $1.4 \times 10^{7}$ & $2.5 \times 10^{7}$ & & $2.3 \times 10^{7}$ \\
\hline & S6 & $1.7 \times 10^{7}$ & & $1.3 \times 10^{7}$ & $2.3 \times 10^{7}$ & & $2.4 \times 10^{7}$ \\
\hline & E53 & $1.4 \times 10^{7}$ & & $1.2 \times 10^{7}$ & $1.3 \times 10^{7}$ & & $1.5 \times 10^{7}$ \\
\hline & $\mathrm{J} 65$ & $1.7 \times 10^{7}$ & & $1.2 \times 10^{7}$ & $4.0 \times 10^{6}$ & & $4.0 \times 10^{6}$ \\
\hline & VP41 & $2.1 \times 10^{6}$ & & $1.9 \times 10^{6}$ & $1.7 \times 10^{6}$ & & $3.0 \times 10^{6}$ \\
\hline
\end{tabular}

study of 113 wine-isolated $O$. oeni strains, 12 strains were positive for the biogenic amine-encoding genes histidine decarboxylase (10 strains) and ornithine decarboxylase (two strains) (Coton et al., 2010).

Although Lactobacillus species have been identified as the main tyramine producers by Moreno-Arribas et al. (2000), L. plantarum has only recently been implicated in the production of biogenic amines (Manfroi et al., 2009). In a screening of 50 wine-isolated L. plantarum strains for biogenic amine-encoding genes by Coton et al. (2010), it was found that only one strain was positive for the agmatine decarboxylase gene and one strain for the tyrosine decarboxylase gene. Contrary to this, both L. brevis and Lactobacillus hilgardii have been identified as producers of tyramine, phenylethyl amine and putrescine, respectively (Arena \& Manca de Nadra, 2001; Landete et al., 2007). In order to totally eliminate the potential for biogenic amine production, screening possible starter cultures for biogenic amine-encoding genes is a quick and efficient method to ensure this.

In order to investigate the potential influence of the potential starter strains on the final wine aroma profile and quality, they were genetically screened for enzymes pertaining to the aroma and flavour profile and wholesomeness of wines undergoing MLF. Some of the biggest differences in the enzymatic profiles of $O$. oeni and L. plantarum were the presence or absence of the genes encoding for the enzymes $\beta$-glucosidase and PAD. Various potentially volatile grapederived aroma compounds exist, but these compounds can be bound to a sugar molecule, rendering them sensorially inactive (D'Incecco et al., 2004; Swiegers et al., 2005). The sugar molecule bound to these compounds usually constitutes a glucose molecule, which denotes that LAB with the ability to demonstrate $\beta$-glucosidase activity could release the volatile compounds to become odour-active, which would enable them to contribute to the sensory profile of the wine (Grimaldi et al., 2000; Boido et al., 2002; Barbagallo et al., 2004; D'Incecco et al., 2004; Matthews et al., 2004; Spano et al., 2005). According to literature, there are conflicting results regarding the absence or presence of enzyme activity in synthetic media/wine-like conditions, as well as under actual wine conditions (Guilloux-Benatier et al., 1993; McMahon et al., 1999; Grimaldi et al., 2000; Mansfield et al., 2002; Barbagallo et al., 2004). Six of the seven (86\%) L. plantarum strains characterised in this study have the potential to release glycosidically bound flavour compounds, compared to the absence of this $\beta$-glucosidase gene in the seven $O$. oeni strains. In our results, which are in accordance with findings by Mtshali (2007), this characteristic seems to be more widespread amongst $L$. plantarum strains than $O$. oeni, although this is a trait than can be an advantageous addition to the selection criteria for MLF starter cultures. Although the $\beta$-glucosidase gene has been characterised in both L. brevis (Michlmayr et al., 2010 ) and L. plantarum (Spano et al., 2005), further characterisation is needed to better understand this liberation process and possible enzyme activity under wine conditions. Lactic acid bacteria are also able to metabolise various phenolic acids present in grape must and wine via PAD activity. These resulting aroma compounds can either impart negative sensorial qualities to the wine or add to the aroma complexity depending on the concentration, which highlights the importance of these genes and the possible contribution to the wine aroma profile (Cavin et al., 1993; Lonvaud-Funel, 1999; Swiegers et al., 2005).

On the other hand, protease activity in wine LAB have 
not been fully investigated or characterised. There is a possibility that LAB protease activity can degrade proteins found in wine and could concomitantly produce amino acids and peptides that could alter the wine aroma profile. The peptidases, including cysteine aminopeptidase, proline iminopeptidase, methionine aminopeptidase and membrane alanine aminopeptidase can potentially contribute to the development of the flavour profile of wine, if enzymes are active under wine conditions, by releasing free amino acids which can serve as precursors for aroma compounds (Matos et al., 1998; Mistou \& Gripon, 1998). The L. plantarum strains also displayed a more diverse peptidase enzyme profile and therefore have a greater chance in releasing amino acids which can serve as aroma compound precursors.

Citrate lyase plays an integral role in the production of the flavour compound diacetyl and this enzyme is responsible for the cleavage of citrate into oxaloacetate and acetate. This is a multi-enzyme complex, consisting of $\gamma-, \alpha$ - and $\beta$-subunits, all of these playing a role in citrate metabolism (Bekal et al., 1998). The enzyme $\alpha$-acetolactate synthase also plays a role in the citric acid metabolism pathway responsible for the production of diacetyl, one of the most important aroma compounds associated with MLF. Our findings are in accordance of those generated by Mtshali et al. (2010) where it was also found that at least $70 \%$ of the L. plantarum strains were positive for one or more of the citrate lyase genes. Therefore L. plantarum strains in our study could potentially play a greater role in the citric acid metabolic pathway and concomitant diacetyl production.

Esterases that originate from wine LAB are responsible for both the biosynthesis and hydrolysis of esters (Matthews et al., 2004; Sumby et al., 2009; Brod et al., 2010). Oenococcus oeni, as well as species of Lactobacillus and Pediococcus, is able to hydrolyse esters and Matthews et al. (2006) found that significant esterase activity levels remained under wine-like conditions. This implies that esterase activity originating from $\mathrm{LAB}$ could potentially contribute to the ester profile. All of the LAB strains screened in our study were positive for the esterase gene, compared to the $70 \%$ of the L. plantarum strains screened by Mtshali et al. (2010). Although our results only confirm the presence or absence of the esterase-encoding gene it remains to be seen if these genes are expressed under wine-conditions and if they synthesise or hydrolyse esters. There is great variation between species and genera with regards to their esterase activity and from available literature, it seems as if $O$. oeni displays the greatest activity, compared to lactobacilli and pediococci (Matthews et al., 2006). Recently, Brod et al. (2010) characterised a novel esterase from L. plantarum and found substrate specificity towards $p$-nitrophenyl-linked substrates, similar to that of $O$. oeni (Matthews et al., 2006).

The additional screening for the presence of enzymes responsible for the formation of volatile sulphur compounds will also be indicative of the potential contribution of the various LAB strains to the wine aroma profile. These enzymes can either catabolise amino acids to produce volatile sulphur compounds like methanethiol and dimethyl disulphide or play a role in the biosynthesis of L-methionine or L-cysteine (Lee et al., 2007; Knoll et al., 2010). Based on the activity of these enzymes, LAB cultures have a profound effect on the production of volatile aroma compounds. Based on our results, it is possible that the $O$. oeni strains could make a slightly greater contribution to the production of volatile sulphur compounds. Despite these results confirming the presence of the gene, during the characterisation of this gene in two O. oeni strains by Knoll et al. (2010), it was found that $O$. oeni seems to play only a minor role in the production of volatile sulphur compounds due to the possible lack of enzyme activity under wine conditions.

The ability to degrade arginine and produce ethyl carbamate precursors have been found amongst both $O$. oeni and L. plantarum strains, although conflicting results in the literature would indicate that this ability is strain dependant. In addition, this characteristic also seems to be more widespread amongst $O$. oeni strains, compared to L. plantarum (Liu et al., 1994, 1995; Mira de Orduña et al., 2000, 2001; Spano et al., 2004; Uthurry et al., 2006; Araque et al., 2009; Romero et al., 2009). These findings in literature are supported by the finding in this study: six of the seven $O$. oeni strains were positive for arginine deiminase and carbamate kinase and all seven were positive for ornithine transcarbamylase. Contrary to this, none of the L. plantarum strains were positive for arginine deiminase, the first enzyme in the pathway that is responsible for the production of ethyl carbamate precursors.

Despite the results of the enzymatic screenings, it needs to be taken into consideration that these PCR reactions only confirm the presence/absence of the genes; it does not give any indication of the expression, if any, of these genes under winemaking conditions, nor is it indicative of the enzymatic activity.

The LAB isolates evaluated during the course of the small-scale fermentation seem to be compatible with the yeast strain $S$. cerevisiae WE372. No immediate or drastic decrease in cell counts was observed after inoculation for MLF, which indicates that metabolites and by-products produced by the wine yeast did not have a detrimental effect on the bacteria. Further investigation is required to elucidate the compatibility of the bacterial isolates with other wine yeast strains as well as the influence of different inoculation regimes on the yeast-bacteria interactions. Despite the fact that the L. plantarum strains took an average of 44 days to complete MLF, compared to nine days required by the O. oeni strains, this experiment served as an initial screening process to establish the ability of the isolates to tolerate the challenging wine environment.

At the completion of this study we were able to select three potential starter strains of $O$. oeni (S5, S6 and E53) and three L. plantarum strains (14.1, 56 and 107) that show potential for future use as malolactic starter cultures. These six strains were selected based on their malic acid degradation ability in wine, their ability to survive the wine environment, as well as their inability to act as major contributors to the volatile acidity concentration. As a result of the characterisation of the isolates, the genetic potential with regards to the production of aroma- and healthimpacting compounds, are known.

In conclusion, this study showed, initially in synthetic medium and then in wine, that both $O$. oeni and L. plantarum have the potential to be utilised as MLF starter cultures when 
used to inoculate after the completion of AF in high alcohol wines. Lactobacillus plantarum strains might have an added beneficial influence in that it has the genetic potential to influence the wine aroma profile to a larger extent than O. oeni, due to its cache of enzymes.

\section{LITERATURE CITED}

Araque, I., Gil, J., Carreté, R., Bordons, A. \& Reguant, C., 2009. Detection of arc genes related with the ethyl carbamate precursors in wine lactic acid bacteria. J. Agric. Food Chem. 57, 1841-1847.

Arena, M.E. \& Manca de Nadra, M.C., 2001. Biogenic amine production by Lactobacillus. J. App. Microbiol. 90, 158-162.

Arena, M.E., Manca de Nadra, M.C. \& Muñoz, R., 2002. The arginine deiminase pathway in the wine lactic acid bacterium Lactobacillus hilgardi $\mathrm{X}_{1} \mathrm{~B}$ : structural and functional study of the $\operatorname{arc} A B C$ genes. Gene 301, 61-66.

Barbagallo, R.N., Spagna, G., Palmeri, R. \& Torriani, S., 2004. Assessment of $\beta$-glucosidase activity in selected wild strains of Oenococcus oeni for malolactic fermentation. Enzyme Microb. Tech. 34, 292-296.

Bekal, S., Diviès, C. \& Prèvost, H., 1998. Citrate lyases of lactic acid bacteria. Lait, 78, 3-10.

Boido, E., Lloret, A., Medina, K., Carrau, F. \& Dellacassa, E., 2002. Effect of $\beta$-glucosidase activity of Oenococcus oeni on the glycosylated flavor precursors of Tannat wine during malolactic fermentation. J. Agric. Food Chem. 50, 2344-2349.

Bou, M. \& Krieger, S., 2004. Alcohol-tolerant malolactic strains for the maturation of wines with average or high $\mathrm{pH}$ (Pub. $\mathrm{N}^{\circ}$ : WO/2004/111179, PCT/FR2004/001421).

Britz, T.J. \& Tracey, R.P., 1990. The combination effect of $\mathrm{pH}, \mathrm{SO}_{2}$, ethanol and temperature on the growth of Leuconostoc oenos. J. App. Bacteriol. $68,23-31$.

Brod, F.C.A., Vernal, J., Bertoldo, J.B., Terenzi, H. \& Arisi, A.C.M., 2010. Cloning, expression, purification, and characterization of a novel esterase from Lactobacillus plantarum. Mol. Biotechnol. 44, 242-249.

Campos, F.M., Couto, J.A. \& Hogg, T.A., 2003. Influence of phenolic acids on growth and inactivation of Oenococcus oeni and Lactobacillus hilgardii. J. Appl. Microbiol. 94, 167-174.

Capozzi, V., Russo, P., Beneduce, L., Weidmann, S., Grieco, F., Guzzo, J. \& Spano, G., 2010. Technological properties of Oenococcus oeni strains isolated from typical southern Italian wines. Lett. Appl. Microbiol. 50, 327334.

Cavin, J.F., Andioc, V., Etievant, P.X. \& Davies, C., 1993. Ability of wine lactic acid bacteria to metabolize phenol carboxylic acids. Am. J. Enol. Vitic. 44, 76-80.

Coton, M., Romano, A., Spano, G., Ziegler, K., Vetrana, C., Desmarais, C., Lonvaud-Funel, A., Lucas, P. \& Coton, E., 2010. Occurrence of biogenic amine-forming lactic acid bacteria in wine and cider. Food Microbiol. 27, 1078-1085

Davis, C.R., Wibowo, D., Fleet, G.H., \& Lee, T.H., 1988. Properties of wine lactic acid bacteria: Their potential enological significance. Am. J. Enol. Vitic. 39, 137-142.

D’Incecco, N., Bartowsky, E., Kassara, S., Lante, A., Spettoli, P. \& Henschke, P., 2004. Release of glycosidically bound flavour compounds of Chardonnay by Oenococcus oeni during malolactic fermentation. Food Microbiol. 21, 257-265.

Downing, L., 2003. Characterisation of biogenic amine-encoding genes in lactic acid bacteria isolated from South African wine. MSc. Thesis Stellenbosch University, Private Bag X1, 7602 Matieland (Stellenbosch), South Africa.
Drici-Cachon, A., Guzzo, J., Cavin, F. \& Diviès, C., 1996. Acid tolerance in Leuconostoc oenos. Isolation and characterisation of an acid resistant mutant. Appl. Microbiol. Biotechnol. 44, 785-789.

Du Toit, M., Engelbrecht, L., Lerm, E. \& Krieger-Weber, S., 2010. Lactobacillus: the next generation of malolactic fermentation starter cultures-an overview. Food Bioprocess Technol. 4: 876-906.

Fugelsang, K.C. \& Edwards, C.G., 1997 (2nd ed). Wine Microbiology: Practical Applications and Procedures. Springer, New York.

Fumi, M.D., Krieger-Weber, S., Déléris-Bou, M., Silva, A. \& Du Toit, M., 2010. A new generation of malolactic starter cultures for high $\mathrm{pH}$ wines. Proceedings International IVIF Congress 2010, WB3 MicroorganismsMalolactic-Fermentation.

G-Alegría, E., López, I., Ruiz, J.I., Sáenz, J., Fernández, E., Zarazaga, M., Dizy, M., Torres, C. \& Ruiz-Larrea, F., 2004. High tolerance of wild Lactobacillus plantarum and Oenococcus oeni strains to lyophilisation and stress environmental conditions of acid $\mathrm{pH}$ and ethanol. FEMS Microbiol. Lett. 230, 53-61.

Grimaldi, A., McLean, H. \& Jiranek, V., 2000. Identification and partial characterization of glycosidic activities of commercial strains of the lactic acid bacterium, Oenococcus oeni. Am. J. Enol. Vitic. 51, 362-369.

Guerrini, S., Mangani, S., Granchi, L. \& Vincenzini, M., 2002. Biogenic amine production by Oenococcus oeni. Curr. Microbiol. 44, 374-378.

Guerzoni, M.E., Sinigaglia, M., Gardini, F., Ferruzzi, M. \& Torriani, S., 1995. Effects of $\mathrm{pH}$, temperature, ethanol, and malate concentration on Lactobacillus plantarum and Leuconostoc oenos: Modelling of the malolactic activity. Am. J. Enol. Vitic. 3, 368-374.

Guilloux-Benatier, M., Son, H.S., Bouhier, S. \& Feuillat, M., 1993. Activite's enzymatiques: glycosidases et peptidase chez Leuconostoc oenos au cours de la croissance bacte'rienne. Influence des amcrolome'cules de levures. Vitis $32,51-57$

Henick-Kling, T., 1993. Malolactic fermentation. In: Fleet, G.H. (ed.). Wine Microbiology and Biotechnology, Harwood Academic Publishers, Chur Switzerland, pp. 289-326.

Jackson, R.S., 2008 (3rd ed). Wine Science: Principles and applications. Academic Press, California, USA. p. 394

Knoll, C., Du Toit, M., Schnell, S., Rauhut, D. \& Irmler, S., 2010. Cloning and characterization of a cystathionine $\beta / \gamma$-lyase from two Oenococcus oen $i$ oenological strains. Appl. Microbiol. Biotechnol. 89, 1051-1060.

Landete, J.M., Ferrer, S. \& Pardo, I., 2005. Which lactic acid bacteria are responsible for histamine production in wine? J. Appl. Microbiol. 99, 580586.

Landete, J.M., Ferrer, S. \& Pardo, I., 2007. Biogenic amine production by lactic acid bacteria, acetic bacteria and yeast isolated from wine. Food Control 18, 1569-1574.

Lee, W.-J., Banavara, D.S., Hughes, J.E., Christiansen, J.K., Steele, J.L., Broadbent, J.R. \& Rankin, S.A., 2007. Role of cystathionine $\beta$-lyase in catabolism of amino acids to sulfur volatiles by genetic variants of Lactobacillus helviticus CNRZ 32. Appl. Environ. Microbiol. 73, 30343039 .

Lerm, E., 2010. The selection and characterisation of lactic acid bacteria to be used as a mixed starter culture for malolactic fermentation. MSc. Thesis, Stellenbosch University, Private Bag X1, 7602 Matieland (Stellenbosch), South Africa.

Lerm, E., Engelbrecht, L. \& Du Toit, M., 2010. Malolactic fermentation: the ABC's of MLF. S. Afr. J. Enol.Vitic. 31, 186-212.

Lewington, J., Greenaway, S.D. \& Spillane, B.J., 1987. Rapid small scale preparation of bacterial genomic DNA suitable for cloning and hybridization analysis. Lett. Appl. Microbiol. 5, 51-53. 
Liu, S.-Q., Pritchard, G.G., Hardman, M.J. \& Pilone, G.J., 1994. Citrulline production and ethyl carbamate (urethane) precursor formation from arginine degradation by wine lactic acid bacteria Leuconostoc oenos and Lactobacillus buchneri. Am. J. Enol. Vitic. 45, 235-242.

Liu, S.-Q., Pritchard, G.G., Hardman, M.J. \& Pilone, G.J., 1995. Occurrence of arginine deiminase pathway enzymes in arginine catabolism by wine lactic acid bacteria. Appl. Environ. Microbiol. 61, 310-316.

Lonvaud-Funel, A., 1999. Lactic acid bacteria in the quality improvement and depreciation of wine. A. van Leeuw. 76, 317-331.

Lonvaud-Funel, A., 2001. Biogenic amines in wine: role of lactic acid bacteria. FEMS Microbiol. Lett. 199, 9-13.

Louw, L., Roux, K., Tredoux, A., Tomic, O., Naes, T., Nieuwoudt, H.H. \& van Rensburg, P., 2009. Characterisation of selected South African young cultivar wines using FTMIR spectroscopy, gas chromatography and multivariate data analysis. J. Agric. Food Chem. 57, 2623-2632.

Manfroi, L., Silva, P.H.A., Rizzon, L.A., Sabaina, P.S. \& Glória, M.B.A., 2009. Influence of alcoholic and malolactic starter cultures on bioactive amines in Merlot wine. Food Chem. 116, 208-213.

Mansfield, A.K., Zoecklein, B.W. \& Whiton, R., 2002. Quantification of glycosidase activity in selected strains of Brettanomyces bruxellensis and Oenococcus oeni. Am. J. Enol. Vitic. 53, 303-307.

Marcobal, Á., De Las Rivas, B., Moreno-Arribas, M.V. \& Muñoz, R., 2005. Multiplex-PCR method for the simultaneous detection of histamine-, tyramine-, and putrescine producing lactic acid bacteria in foods. J. Food Protect. 68, 874-878

Matos, J., Nardi, M., Kumura, H. \& Monnet, V., 1998. Genetic characterisation of $p e p C$, which encodes an aminopeptidase $\mathrm{P}$ whose deficiency does not affect Lactococcus lactis growth in milk, unlike deficiency of the x-prolyl dipeptidyl aminopeptidase. Appl. Environ. Microbiol. 64, 4591-4595.

Matthews, A., Grimaldi, A., Walker, M., Bartowsky, E., Grbin, P. \& Jiranek, V., 2004. Lactic acid bacteria as a potential source of enzymes for use in vinification. Appl. Environ. Microbiol. 70, 5715-5731.

Matthews, A.H., Grbin, P.R. \& Jiranek, V., 2006. A survey of lactic acid bacteria for enzymes of interest to oenology. Aust. J. Grape Wine Res. 12, $235-244$.

McMahon, H., Zoecklein, B.W., Fugelsang, K. \& Jasinsky, Y., 1999. Quantification of glycosidase activities in selected yeasts and lactic acid bacteria. J. Ind. Microbiol. Biotechnol. 23, 198-203.

Michlmayr, H., Schümann, C., Barreira Braz da Silva, N.M., Kulbe, K.D. \& Del Hierro, A.M., 2010. Isolation and basic characterisation of a $\beta$-glucosidase from a strain of Lactobacillus brevis isolated from a malolactic starter culture. J. Appl. Microbiol. 108, 550-559.

Mira de Orduña, R., Liu, S.-Q., Patchett, M.L. \& Pilone, G.J., 2000. Ethyl carbamate precursor citrulline formation from arginine degradation by malolactic wine lactic acid bacteria. FEMS Microbiol. Lett. 183, 31-35.

Mira de Orduña, R., Liu, S.-Q., Patchett, M.L. \& Pilone, G.J., 2001. Growth and arginine metabolism of the wine lactic acid bacteria Lactobacillus buchneri and Oenococcus oeni at different $\mathrm{pH}$ values and arginine concentrations. Appl. Environ. Microbiol. 67, 1657-1662.

Mistou, M.-Y. \& Gripon, J.-C., 1998. Catalytic properties of the cysteine aminopeptidase pepC, a bacterial bleomycin hydrolase. Biochim. Biophys. Acta $1383,63-70$.

Moreno-Arribas, V., Torlois, S., Joyeux, A., Bertrand, A. \& Lonvaud-Funel, A., 2000. Isolation, properties and behaviour of tyramine-producing lactic acid bacteria from wine. J. Appl. Microbiology, 88, 584-593.
Mtshali, P.S., 2007. Screening and characterisation of wine-related enzymes produced by wine-associated lactic acid bacteria. Thesis, Stellenbosch University, Private Bag X1, 7602 Matieland (Stellenbosch), South Africa.

Mtshali, P.S., 2010. Personal communication.

Mtshali, P.S., Divol, B.T., Van Rensburg, P. \& Du Toit, M., 2010. Genetic screening of wine-related enzymes in Lactobacillus species isolated from South African wines. J. Appl. Microbiol. 108, 1389-1397.

Pozo-Bayón, M.A., G-Alegría, E., Polo, M.C., Tenorio, C., Martín-Álvarez, P.J., Calvo de la Banda, M.T., Ruiz-Larrea, F. \& Moreno Arribas, M.V., 2005. Wine volatile and amino acid composition after malolactic fermentation: Effect of Oenococcus oeni and Lactobacillus plantarum starter cultures. J. Agric. Food Chem. 53, 8729-8735.

Romero, S.V., Reguant, C., Bordons, A. \& Masqué, M.C., 2009. Potential formation of ethyl carbamate in simulated wine inoculated with Oenococcus oeni and Lactobacillus plantarum. Int. J. Food Sc. Technol. 44, 1206-1213.

Rosi, I., Nannelli, F. \& Giovani, G., 2009. Biogenic amine production by Oenococcus oeni during malolactic fermentation of wines obtained using different strains of Saccharomyces cerevisiae. Food Sc. Technol. 42, 525530 .

Ruiz, P., Izquierdo, P.M., Seseña, S. \& Palop, M.L., 2010. Selection of autochthonous Oenococcus oeni strains according to their oenological properties and vinification results. Int. J. Food Microbiol. 137, 230-235.

Solieri, L., Genova, F., De Paola, M. \& Giudici, P., 2010. Characterization and technological properties of Oenococcus oeni strains from wine spontaneous malolactic fermentations: a framework for selection of new starter cultures. J. Appl. Microbiol. 108, 285-298.

Spano, G., Chieppa, G., Beneduce, L. \& Massa, S., 2004. Expression analysis of putative $\operatorname{arc} A, \operatorname{arc} B$ and $\operatorname{arc} C$ genes partially cloned from Lactobacillus plantarum isolated from wine. J. Appl. Microbiol. 96, 185193.

Spano, G., Rinaldi, A., Ugliano, M., Moio, L., Beneduce, L. \& Massa, S., 2005. A $\beta$-glucosidase gene isolated from wine Lactobacillus plantarum is regulated by abiotic stresses. J. Appl. Microbiol. 98, 855-861.

Sumby, K.M., Matthews, A.H., Grbin, P.R. \& Jiranek, V., 2009. Cloning and characterization of an intracellular esterase from the wine-associated lactic acid bacterium Oenococcus oeni. Appl. Environ. Microbiology, 75, 6729-6735.

Swiegers, J.H., Bartowsky, E.J., Henschke, P.A. \& Pretorius, I.S., 2005. Yeast and bacterial modulation of wine aroma and flavour. Aust. J. Grape Wine Res. 11, 139-173.

Terrade, N. \& Mira de Orduña, R., 2009. Determination of the essential nutrient requirements of wine-related bacteria from the genera Oenococcus and Lactobacillus. Int. J. Food Microbiol. 133, 8-13.

Ugliano, M., Genovese, A. \& Moio, L., 2003. Hydrolysis of wine aroma precursors during malolactic fermentation with four commercial starter cultures of Oenococcus oeni. J. Agric. Food Chem. 51, 5073-5078.

Uthurry, C.A., Suárez Lepe, J.A., Lombardero, J. \& Garcia Del Hierro, J.R., 2006. Ethyl carbamate production by selected yeasts and lactic acid bacteria in red wine. Food Chem. 94, 262-270.

Vivas, N., Lonvaud-Funel, A. \& Glories, Y., 1997. Effect of phenolic acids and anthocyanins on growth, viability and malolactic activity of a lactic acid bacterium. Food Microbiol. 14, 291-300.

Wibowo, D., Eschenbruch, R., Davis, D.R., Fleet, G.H. \& Lee, T.H., 1985. Occurrence and growth of lactic acid bacteria in wine: A review. Am. J. Enol. Vitic. 36, 302-313. 